TI 2014-001/V

Tinbergen Institute Discussion Paper

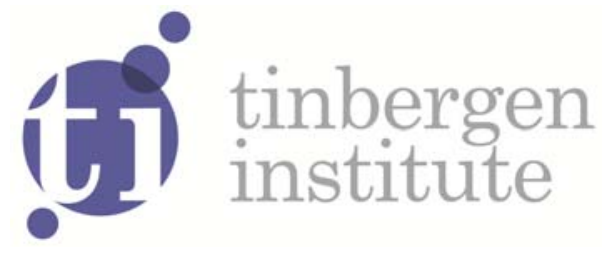

\title{
Making Work pay for the Indebted. The Effect of Debt Services on the Exit Rates of Unemployed Individuals
}

Pierre Koning

Faculty of Economics and Business Administration, VU University Amsterdam, Tinbergen Institute, The Netherlands, IZA, Germany. 
Tinbergen Institute is the graduate school and research institute in economics of Erasmus University Rotterdam, the University of Amsterdam and VU University Amsterdam.

More TI discussion papers can be downloaded at http://www.tinbergen.nl

Tinbergen Institute has two locations:

Tinbergen Institute Amsterdam

Gustav Mahlerplein 117

1082 MS Amsterdam

The Netherlands

Tel.: +31(0)205251600

Tinbergen Institute Rotterdam

Burg. Oudlaan 50

3062 PA Rotterdam

The Netherlands

Tel.: +31(0)10 4088900

Fax: $+31(0) 104089031$

Duisenberg school of finance is a collaboration of the Dutch financial sector and universities, with the ambition to support innovative research and offer top quality academic education in core areas of finance.

DSF research papers can be downloaded at: http://www.dsf.nl/

Duisenberg school of finance

Gustav Mahlerplein 117

1082 MS Amsterdam

The Netherlands

Tel.: +31(0)20 5258579 


\title{
Making Work Pay for the Indebted. The Effect of Debt Services on the Exit Rates of Unemployed Individuals
}

\author{
PIERRE KONING \\ VU UNIVERSITY AMSTERDAM, IZA AND TINBERGEN INSTITUTE \\ P.O. BOX 80510 \\ DE BOELELAAN 1105 \\ 1081 HV AMSTERDAM \\ THE NETHERLANDS \\ TEL: +31-70-3334009 \\ EMAIL: P.W.C.KONING@VU.NL
}

December 2013

DWI Amsterdam is gratefully acknowledged for providing the data that are used in this paper. In particular, I would like to thank Peppie Pilipiec and Nora Grundel for providing assistance in preparing the data. 


\begin{abstract}
This paper investigates the effectiveness of an intervention that was targeted at a specific group of Dutch Social Assistance (SA) recipients with debt problems. With a large share of the income gains of work resumption were transferred to the creditors, these individuals experienced a strong a priori disincentive to resume formal work. The direct aims of this intervention were therefore twofold: the restructuring of personal debts and the prevention of new debt problems to arise. We use the timing-of-events method to identify the effects of debt programs on SA spells. Our key finding is that the provision of debt services substantially increased the exit out of the SA schemes, but this was mainly due to exits out of the labor force. This suggests individuals perceived or experienced program as unpleasant and opted to exit without work. At the same time, the debts program offer increased the exit rate for targeted individuals that did not show up, probably due to increased monitoring and sanction activities.
\end{abstract}




\section{INTRODUCTION}

In many Western countries, an increasing share of unemployed workers is faced with personal debts. The consequences of these debts on work incentives can be substantial. Particularly with bankruptcy systems that are creditor oriented - like in many European countries - a large share of the income gains due to work resumption are transferred to the creditors for an extensive period of time. Particularly if personal discount rates are high, repay obligations may induce individuals to search less for jobs - see White (2011) for a survey on the personal bankruptcy literature. ${ }^{1}$

With debts as an important impediment for work resumption, Unemployment Insurance (UI) and Social Assistance (SA) benefit administrations have an interest in the settlement of claims of their clients. Public social benefit administrations may also be relatively well suited to co-ordinate the actions of creditors and arrange an informal workout to restructure debts. To the best of our knowledge, however, there is no empirical evidence on the use and usefulness of such programs for unemployed workers. In a broader context, empirical analyses on the effects of household debt restructuring on labor supply are limited as well (White 2011).

This paper tries to break ground by studying the effectiveness of an intervention that was targeted at a specific group of Dutch SA recipients with debt problems that lived in the city of Amsterdam, the largest city of the Netherlands (with about 800,000 inhabitants). The direct aims of this intervention were essentially twofold: the restructuring of personal debts and prevention of new debt problems to arise. First, individuals were assisted in the restructuring of their debts and alerted on their entitlement to income supplements other than SA benefits. The aim of these activities was to stabilize or solve debt problems. If clients did not succeed in debt restructuring, they were prepared for their eligibility to a formal, judicial debt restructuring program that would

\footnotetext{
${ }^{1}$ In contrast to this, the most commonly used personal bankruptcy procedure in the US exempts all future earnings from the obligation to repay (this is commonly referred to as the 'fresh start').
} 
be far more time consuming - and without interference of the SA benefit administration. Second, training programs were offered to individuals to improve their budgeting and financial literacy skills. In these trainings, the aim was to learn individuals to get financially well organized and understand the necessity of paid work.

The key research question in this paper is whether the debt program contributed to the exit rates of the targeted group of SA recipients. We measure these effects both during as well as after the provision of the debt services program. In addition, a special interest lies in potential threat effects among targeted individuals that did not participate in the program - the so called 'noshows'. For this group, the non-acceptance of the program was not without consequences, as it increased the likelihood of sanctions and intensive monitoring activities of caseworkers.

We use administrative data on both the SA unemployment spells, the occurrence of debt service offers, and the occurrence of actually starting the debts program that was offered (or not). With these data, we estimate hazard rate and Logit models to identify the effects of the debt services. The identification of program effects is based on the assumption that SA recipients cannot anticipate the exact timing of a debt program offer - i.e. the 'timing-of-events' method (Abbring and Van den Berg 2003). This method takes account of the possibility that both targeted individuals that started the program and those who did not start the program were selective.

This paper connects and contributes to various strands of literature. To start with, there is a continuing stream of papers that addresses the effectiveness of active labor market policies (ALMP's); see Kluve (2010) and Card et al. (2010) for a survey studies. While there is a substantial variation in the types of ALMP's and types of worker groups that are studied, the current study focuses on an intervention that can be characterized as non-conventional. Typically, the literature addresses instruments that directly improve the job opportunities of workers by offering job training, job mediation, wage subsidies, or subsidized employment. The idea behind 
the use of the debt program, however, was to remove the incentive barriers that prevented individuals to accept jobs and improve their 'soft skills' to prevent future debts.

As a second contribution, we build upon recent work on the importance of threat effects of mandatory job programs - see Andersen (2013) for a recent survey. ${ }^{2}$ Threat effects are typically defined as increases in re-employment rates prior to the actual start of programs, when workers are already informed on the starting date (Graversen and Van Ours 2008; Geerdsen 2006; Rosholm and Svarer 2008). The implicit assumption is that mandatory programs are enforced for all workers that receive benefits at the time the program starts. A common finding of this literature is that threat effects are substantial in the relevant time interval, particularly when compared to the effects during and after job programs. Presumably, unemployed workers derive disutility from job programs due a loss of leisure time and more interference by their caseworkers and try to avoid program participation by searching more actively for jobs.

Within the context of the current analysis, it is likely that threat effects were important too, but worked in different ways. Program participants had to provide a full overview of their financial situation and their income components. We argue that therefore some individuals were not eager to participate, since this harmed their privacy or - worse - would reveal income fraud. In addition, individuals also may have derived disutility from participating in the meetings and courses in itself. Contrasting to the standard literature - and despite the fact that programs were not provided on a voluntary basis - about one third of the clients that was contacted did not participate. In the current context, we therefore define threat effects as the change in exit rates of the 'no-shows', starting from the moment that they were contacted to participate in the program.

\footnotetext{
${ }^{2}$ This literature complements studies on the effect of sanctions on return to work rates (Van der Klaauw and Van Ours 2011; Abbring et al. 2005; Van den Berg et al. 2004; Lalive et al. 2005; Jensen et al. 2003; Boockman et al. 2009).
} 
Similar to the analyses of Hagglund (2006), Arni et al (2013) and Frijters and Van der Klaauw (2006), we also pay special attention to the exit rates into non-participation. Since no-shows took the risk of increased monitoring or getting sanctioned by their caseworker, they also may have opted to leave the SA scheme without work resumption. Stated differently, some of them may have left paid unemployment for unregistered unemployment in order to avoid pressures exerted by the sanction system and to 'gain' more time for job search.

As a third contribution, our analysis is related to recent work on discounting and the job search behavior of unemployed workers. Since the seminal paper of Della Vigna and Paserman (2006), it has widely been acknowledged that hyperbolic discounting of unemployed individuals may lower their return to work rates. ${ }^{3}$ The idea is that impatient workers search less intensively for work. This effect dominates the effect of lower reservation wages and higher job acceptance rates that impatient unemployed workers have. As unemployed workers with debts are prone to hyperbolic discounting, the targeted SA recipients in the city Amsterdam may have undervalued the future rewards of participation in the debts program. This may also explain why a large share of the targeted population did not participate in the debts program.

Finally, this paper adds to the empirical literature on the effects of personal bankruptcy. This literature focuses on the consequences of between state variation in exemption levels for wealth in the US on the behavior of debtors and creditors. Zooming into the post bankruptcy behavior of labor supply and work effort, however, the evidence is limited. Within the context of US bankruptcy law, filing for bankruptcy reduces rather than increases the obligations to repay

\footnotetext{
${ }^{3}$ When taking a broader perspective, our analysis also builds upon the literature on personality traits or 'soft skills' are adequate predictors of success or failure (Heckman and Kautz 2012). In this respect, of the 'Big Five' of personality traits the conscientiousness of individuals - i.e. the tendency to be hardworking and organized - is the most relevant one.
} 
debt from earnings. Although one would expect the work incentive to increase as a result for this, Han and Li (2007) find no evidence that this increases the labor supply of individuals in the US.

The key finding of this paper is that debt services increased the exit out of the SA scheme. The provision of a standard debt services program participation completed increased the exit probability with $8 \%$-point, measured two years after the start of an unemployment spell. More strikingly, this effect can largely be attributed to increased inflow into non-participation. This suggests that participants experienced the program as a disutility and therefore opted to leave the SA scheme without formal work. We also find that offering the debts program increased the exit rate for targeted individuals that did not participate in the program - i.e. the 'no-shows'. Again, this probably mirrors the effect of increased monitoring and sanction activities for this group.

The paper proceeds as follows. Section 2 explains the institutional settings of the SA benefit scheme in the Netherlands, as well as the motivation and the design of the debts program that was started by the city of Amsterdam. We also provide a description of the data in this section. Section 3 explains the empirical strategy we use to assess the impact of the program. Section 4 presents estimation results and Section 5 concludes. 


\section{INSTITUTIONAL SETTINGS AND DATA}

\subsection{Social assistance benefits and Welfare-to-Work programs}

In the Netherlands, SA benefits form a safety net that provides support to unemployed workers who are not entitled to any other social insurance benefits such as Unemployment Insurance or Disability Insurance benefits. The administration of SA benefits is carried out by municipalities. SA benefits are both means and asset tested and related to the family income. Individuals should own more than 5,765 euros net worth of assets and households with more persons are exempted for assets worth 11,895 euro at maximum. As long as these conditions are met, SA benefits are not limited in duration. SA benefits are about 1,000 euros per month for single households, which is somewhat higher than in most other European countries.

Although SA benefit rights are determined at the national level, Dutch municipalities have considerable discretion in the design of their activation policies. The costs of these policies can be financed by the conditional block grants they receive from the ministry of Social Affairs and Employment (Faber and Koning 2012). Of the total budget of 1.4 billion euros in 2010, 49\% was spent on various types of Welfare-to-Work trajectories, $27 \%$ on wage subsidies and $24 \%$ on subsidized employment (RWI 2012). The actual design of Welfare-to-Work trajectories differed between municipalities, ranging from 'social activation' to job training and mediation programs for clients.

In the time period under investigation the city of Amsterdam used a (subjective) profiling system to target their Welfare-to-Work services. This system distinguished five categories of individuals. Three of these categories consisted of individuals that were not expected to find a job without any long lasting interventions. Only two of these categories - amounting to $23 \%$ of the inflow in the SA scheme - were profiled as having sufficient job skills and had to search actively 
for jobs. ${ }^{4}$ For one of these two categories mediation and job search services were provided. The other group of clients did not receive any support. Debt programs were not targeted to one classification group in particular.

\subsection{Priority Care Debt Services}

In June 2008 the social benefit administration of Amsterdam (DWI) announced its plans to provide debt services for SA client with debts (DWI 2008). DWI contracted two private organizations to provide debt services between November 2008 and July 2012 (Westerbeek and Plangroep). The argument of DWI was that for many clients personal debts were a major impediment for work resumption. In the Netherlands, creditors are entitled to claim $90 \%$ of all additional income due to work resumption. Related to this argument, employers may find SA clients with debts unattractive for administrative reasons. For these workers, they have to cooperate in transferring earnings to creditors.

DWI labeled the program as 'Priority Care Debt Services' (PCDS), referring to the fact that it intended to speed up the intake and treatment process for SA recipients with debts. ${ }^{5}$ From the perspective of the municipality, the financial losses of the needless prolongation and increases of debts could be high. SA recipients were therefore diagnosed on their financial conditions right from the start of their benefit spell. There were no formal rules for the allocation of the debt programs - this decision essentially was at the discretion of the casemanagers. Clients were informed that they were offered a debt program in a meeting with casemanager, after which it could take two weeks at maximum before the program started.

\footnotetext{
${ }^{4}$ See Section 2.2 for a more extensive explanation of the profiling and targeting system.

${ }^{5}$ Until that time, these individuals only had access to debt services that were provided by quarters in the city of Amsterdam, and were only were eligible if they had very substantial debts. DWI Amsterdam argued this would be overly time-consuming and thus would involve additional, unnecessary SA benefit expenses.
} 
The Priority Care Debt Services system prescribed that the debt program was not optional for clients. Clients were expected to cooperate with their caseworkers and the debt services providers. Temporary benefit reductions could be used to sanction individuals in case of noncompliance. In light of the specific problems clients had, however, the aim of the benefit administration was to avoid the use of this instrument. Unfortunately, there is no official registration of imposed sanctions that can be used for the current analysis.

Priority Care Debt Services involved two types of services. First, individuals were assisted in the informal restructuring of their debts and - if necessary - alerted on their entitlement to income supplements. The aim of these activities was to stabilize financial debt problems. For this purpose, both debt service organizations started by gathering all relevant information on creditors and the size of debts. Clients thus had to provide full access to their financial administration. Personal debts mostly originated from fines, electricity or gas bills, (local) taxes, telephone bills, rents, insurance premiums, and medical treatments that were unpaid. In addition, debts stemmed from products that were bought on credit and loans from banks. Debt service providers assisted clients in contacting their creditors and requested a reduction of their debts and/or a relaxation of payment conditions. ${ }^{6}$ This part of the program was most time consuming. The debt providers also checked whether clients were eligible to several tax deductions - e.g. for lone parents - or income subsidies that were not effectuated.

The second type of services that were provided were budgeting courses. These courses, which aimed at increasing the financial literacy of clients and the skill get financially wellorganized, could last six months at maximum.

\footnotetext{
${ }^{6}$ Unfortunately, the reduction of claims is not registered in the databases of DWI. From talks with several casemanagers, we infer that on average about $75 \%$ of personal debts is cleared.
} 
In total, the debts programs were meant to last one year at maximum per client. Typically, the program consisted of about five meetings with employers of the debt services organization with eight meetings at maximum. Prior to these meetings, participants had to prepare information and learn the course material. When clients successfully completed the program, there were three possible outcomes. The first one was that clients succeeded in 'financial stabilization', with no further direct need of debt services. Second, the outcome could be the start of a formal, judicial personal bankruptcy procedure. From the perspective of both the client and the social benefit administration, the outcome of such a process - which usually are very time-consuming - would harm work incentives for a long time. Third, if debts were not too substantial, the city of Amsterdam arranged the settlement of debts by taking over the claims of individual creditors.

\subsection{Unemployment spells}

For our analysis we have an administrative sample of 29,855 unemployed spells of workers between the age of 18 and 65 that have entered into the SA benefit scheme between November 2008 and December 2011. Benefit durations that have not ended are right censored at the first of July in 2012. 23,769 SA benefit spells in our sample are of individuals that are observed once. ${ }^{7}$ For all clients that received SA benefits in the time period under consideration, we observe the age, gender, education level, household status and their profiling category. We also observe whether a client participated in work programs of the municipality that were unpaid. These were particularly relevant for younger workers, which had to study or participate in work programs in order to be eligible for SA benefits.

\footnotetext{
${ }^{7}$ 2,705 individuals have two SA spells; 212 have three SA spells; 10 individuals have four SA spells; and one individual has five SA spells.
} 


\section{< INSERT TABLE 1 HERE >}

The second column of Table 1 presents the sample statistics of our full sample. Clearly, job prospects of the inflow cohorts were poor, with low education levels, mostly single household statuses and with profiling categories that qualify clients are having a lack of job and social skills as well. In line with this, we find the average of completed SA benefit spells to equal about 11 months and only about $30 \%$ of completed spells is registered to end into regular employment. ${ }^{8}$ It is important to stress that these figures are not officially registered by DWI Amsterdam, but derived from the reported descriptions of caseworkers when their clients left the SA scheme. In practice, this means that reported destinations are missing for $29 \%$ of the exits. Reasons for ending SA benefit spells other than work resumption include the imposition of sanctions due to insufficient search activities or income fraud (20\%); the inflow into other social insurance schemes, such as retirement (10\%); moving outside the city (8\%); and returning to school (2\%).

\section{< INSERT FIGURES 1 AND 2 HERE >}

Figure 1 shows the survival rates for the sample of benefit spells. After one year, only $25 \%$ of the spells had ended for the group of individuals that was not offered a debts program. In addition, Figure 2a shows that the hazard from the SA scheme to work has the familiar pattern of negative duration dependency. For the hazard rate to other destinations that is shown in Figure

\footnotetext{
${ }^{8}$ As the destination is unknown for $29 \%$ of the uncensored spells, the percentage of exit into work is likely to be an underestimate. Assuming that missing observations are proportionally distributed, $42 \%$ of the exits would be due to work resumption. This percentage comes close to the estimate of Kok et al. (2008) of 40\%. Kok et al. use also data for SA recipients in the city of Amsterdam, but then for the period 2001-2007.
} 
$2 \mathrm{~b}$, however, the picture is less pronounced - with some spikes at moments when the eligibility of clients was re-examined.

\subsection{Debt programs and debts}

In addition to the benefit spells, we have 2,940 records of unique SA clients that were targeted for the debt services programs. For clients that started the program we observe a sequence of dates they showed up at the two debt service organizations - with the first date starting one month after contacting date at maximum. For each date the corresponding activities are registered, together with an assessment whether these activities were completed, or not. Debts programs are successfully completed if they lead to one of the aforementioned three outcomes: 'financial stabilization', the start of a formal personal bankruptcy procedure, or inflow info the municipality creditor program. Debt programs are measured starting from the date of the first activity and ending at the date of the last activity that was reported. ${ }^{9}$ We thus end up with a sample of unique individual debt programs. We have merged these debt program spells to the sample of SA benefit spells. Debt programs could start and end prior to, during or after an individual SA benefit spell.

\section{< INSERT FIGURES 3 AND 4 HERE >}

Figure 3 shows the hazard rates of receiving a debt program offer. As we focus on the inflow of SA benefit recipients, almost all offers occur in the first three months of the SA benefit spell. This mirrors the fact that the financial assessment was mostly carried out at the moment of

\footnotetext{
${ }^{9}$ This mean that programs that were suspended for a while and then re-started after a while by are merged to one another. Thus, for the empirical analysis the intervening duration without debt program activities is also included in the program.
} 
SA intake, with program offers that were sent out at short notice. Figure 4 shows the distributions debt program lengths for completed programs and program that were censored due to exit of the SA scheme, respectively. The average length was about nine months in both cases. About one third of the durations lasted longer than the norm of one year.

The third column of Table 1 shows that the subsample of 2,940 clients that were offered a debt program is relatively young, male, more likely to join unpaid work programs, lower educated, and most likely to be a single parent. In line with this, individuals that are profiled a having a lack of job skills are overrepresented in the group that is offered a debt program. This however does not mean that the SA exit rates of the targeted group of individuals are lower as well. Figure 1 shows that the group of participants has SA survival rates that are comparable to the individuals without a debt program offer, whereas the no-shows tend to leave the scheme even faster. For a large part, this mirrors the fact that the targeted group is relatively young.

Columns (iv) to (vi) of Table 1 show that the fractions of 'no-shows' (44\%) and unfinished programs (21\%) are substantial. Thus, only about 35\% of the targeted group of SA clients succeeds in completing the debts program. Women, single parents and older workers are more likely to accept the debts program, whereas the opposite holds for individuals participating in unpaid work programs. We also find debt program participants to have longer SA benefit spells, but this largely reflects reverse causality.

\section{< INSERT FIGURES 5 AND 6 HERE >}


Unfortunately, we only observe information on the reported debts and the number of creditors for 1,710 of the 1,944 clients that started the debts program. ${ }^{10}$ Figure 5 shows the distribution of reported debts that follows from these data. The majority of clients that started a program has debts that are not very substantial, with a medium value of 12,500 euros. Still, the highest percentile has debts of about 42,000 euros and more. When zooming into the group of clients that successfully ends the debts program, the average debt is equal to about 33,000 euros. It thus seems that clients with more severe debt problems were more interested in debts restructuring and more likely to complete the program as well.

To gain more insight in the determinants of personal debts, Table 2 shows the estimation results from an OLS regression with individual characteristics of program participants as explanatories. Clearly, age is the most important driver of debt size that is observed in our data. Debts are lowest for individuals below the age of 25 (about 9,500 euros on average), increase up to the age of 35, and then remain more or less stable. We also find individuals in unpaid work programs to have lower debt rates. Debts increase in the number of education years. The household composition, profiling category and the year of inflow into the program do not have a significantly affect debt size.

Finally, Figure 6 presents a distribution of the number of creditors per client for which debts are observed. Although about $30 \%$ of the individuals only has one creditor, on average there are 9.5 creditors per individual. In this respect, it should be noticed that the highest percentile in this distribution has more than 22 creditors(!). As a result, the average debt of clients per creditor is not too substantial in most cases. The value average of the individual debt per creditor is close to 3,000 euro, and the medium value is 1,750 euro.

\footnotetext{
${ }^{10}$ As a consequence, estimating model variants with debts information as controls is not viable.
} 
The picture that emerges is that debt problems for the targeted group of SA clients were not substantial in all cases. Still, in this context the informal settlement of claims was unlikely to occur. In particular, the co-ordination of informal claims settlement was not straightforward, with many creditors per individual. One should also take in mind that SA clients are both means and wealth tested, implying that their potential to pay off debts is limited. When supposing that $10 \%$ of the SA benefits of a single household would be transferred to creditors, it would take 20 years (!) to fully repay a debt of 20,000 euros. 


\section{EMPIRICAL IMPLEMENTATION}

To identify the effect of the debts program on the hazard out of SA benefit spells, our key assumption is that the timing of debt program offers is not anticipated by the SA recipients. This method, which is used often for the evaluation of active labor market programs, is referred to 'timing-of-events' approach (Abbring and Van den Berg 2003). Adopting the non-anticipation assumption does not mean that the provision of debt programs is random. Instead, it allows the likelihood of debt program offers to be determined by observed and time constant unobserved characteristics (i.e. 'random effects'). SA recipients may be well aware they are likely to be contacted by their caseworker and offered a debt program, but they do not know the exact timing of this event.

Within the context of the debt program that was provided, the non-anticipation assumption can be justified by the short time span between the announcement and the start of the debt programs that clients were invited for. This means clients could only change their behavior in two weeks. As we observe only 10 clients that were targeted that left the SA scheme in this period after notification, anticipation effects are probably small. ${ }^{11}$

For the targeted group of participants we observe debt programs that have started. The effect on program participants on the transition rate out of SA is specified both during and after the program. For the group of no-shows, however, we only observe the date at which the program offer was sent out and the date the program should have started. We assume threat effects for this group to start after the supposed starting date; we interpret this as the effect of increased

\footnotetext{
${ }^{11}$ Van der Klaauw and Kastoryano (2011) use a similar argument to justify the use of the non-anticipation assumption to estimate program effects. They argue that program participants were informed two weeks in advance. As another example, Van den Berg et al. (2012) evaluate the effect of meetings with caseworkers which are announced one week in advance.
} 
sanctioning and monitoring activities of caseworkers. It should be stressed that the estimation of both the intended treatment effects and threat effects relies upon the no-anticipation assumption. This means that the decision of starting of the debt program offer is made at the moment the debt program should start. As the actual start of programs followed one or two weeks after the notification, this is not a strong assumption to make.

To formalize matters, consider an individual entering SA at date $\tau_{0}$, who has been unemployed for $t$ days. The exit rate from SA does not only depend on calendar time $\tau_{0}+t$ and the elapsed duration of SA benefits $t$, but also on observed individual characteristics $\boldsymbol{x}$ and unobserved characteristics $v_{u}$. Furthermore, we denote $t_{d}$ as the elapsed duration of receiving an offer to participate in the debts program. Individuals can either start the program $(d=1)$ or not participate $(d=0)$. If an SA recipients starts the program, we also observe $t_{c}$, which is defined as the elapsed SA duration of completing the debts program. For the SA recipient the exit rate is then assumed to follow a Mixed Proportional Hazard (MPH) rate:

$$
\begin{gathered}
\theta_{u}\left(t \mid x, \tau_{0}, d, t_{s}, t_{c}, v_{u}\right)=\lambda_{u}(t) \psi_{u}\left(\tau_{0}+t\right) \exp \left\{x \beta_{u}+\delta_{1} I(d=1) \times I\left(t_{s}<t \leq t_{c}\right)+\right. \\
\left.\delta_{2} I(d=1) \times I\left(t>t_{c}\right)+\delta_{3} I(d=0) \times I\left(t>t_{s}\right)+v_{u}\right\}
\end{gathered}
$$

where $\lambda_{u}(t)$ is a piecewise constant function that represents genuine duration dependence and $\psi_{u}\left(\tau_{0}+t\right)$ are genuine calendar time effects that are modeled as yearly dummies. The indicator $I$ is a dummy that is equal to one (zero) for the event between parentheses. $v_{u}$ denotes the effect of (time constant) unobserved characteristics. The parameters $\delta_{1}, \delta_{2}$ and $\delta_{3}$ describe the effects of the debt program on the transition rate out of the SA scheme. For debt program participants, $\delta_{1}$ and $\delta_{2}$ are the effect during the program - sometimes referred to as 'lock-in' effects if job 
search activities are lowered at that time - and the effect after program completion, respectively. For the targeted group that does not participate, $\delta_{3}$ is a permanent effect that stems from increased sanctioning and monitoring activities. This effect comes into force at $t_{s}$.

It is likely that both the likelihood of being offered a debts program and that of showing up at the start are correlated with the transition rate out of the SA scheme $\theta_{u}$. Following Abbring and Van den Berg (2003), we therefore propose a multivariate framework that also explains both the transition rate of debt program offers and that of the probability that the offer is accepted. Analogous to the notation and setup as in equation [1], equation [2] specifies the transition rate of a debt program offer at time $t$ as follows:

$$
\theta_{p}\left(t \mid x, \tau_{0}, v_{p}\right)=\lambda_{p}(t) \psi_{p}\left(\tau_{0}+t\right) \exp \left\{\boldsymbol{x} \beta_{p}+v_{p}\right\}
$$

Similar to the transition rate out of SA, the hazard of receiving a debt program offer is driven by genuine duration dependence, calendar time effects, and observed and unobserved individual characteristics. The coefficients describing these effects are indexed with the subscript 'p'.

Conditional on the debt program offer, we finally model the probability of starting the program $P_{d}$ as a Random Effects Logit specification with genuine duration dependence and observed and unobserved characteristics as explanatory variables.

$$
P_{d}\left(d \mid x, v_{p}\right)=1 /\left\{1+\exp \left\{-\psi_{d}\left(\tau_{0}+t\right)-\boldsymbol{x} \beta_{d}-v_{d}\right\}\right\}
$$

To account for selectivity in the unobserved components of the exit rate from SA benefits, the debt program offer rate and the conditional probability of starting the debt program $-v_{u}, v_{p}$ and 
$v_{d}$ - are allowed to be correlated. We therefore take the joint distribution of the unobserved heterogeneity terms $v_{u}, v_{p}$ and $v_{d}$ to be trivariate discrete with unrestricted mass point locations for each term. When having $K$ possible mass points, the associated probabilities are denoted as follows:

$$
p_{k}=\operatorname{Pr}\left(v_{u}=v_{u}^{k}, v_{p}=v_{p}^{k}, v_{d}=v_{d}^{k}\right) \quad \text { for } \quad k=1, \ldots K
$$

with $0 \leq p_{k} \leq 1$ and $p_{K}=1-p_{1}-. .-p_{K-1}$ as restrictions.

We use Maximum Likelihood estimation to estimate all parameters in equations [1], [2] and [3]. For the total maximum likelihood function, there can be three likelihood contributions per individual at maximum, depending on the event of receiving a debt program offer (or not). First, for each individual there are one or more SA benefit spells that may or may not be rightcensored. Second, as long as debt programs have not been offered to this individual in a previous SA spell, we observe the duration until a debt program offer is received. As only about $10 \%$ was targeted, these durations are mostly right-censored. Third, when a debt program is offered, the third contribution explains the likelihood of a dummy describing the event of starting the debt program (or not). This third part falls out of the likelihood if there is no debt program offer.

To specify the log-likelihood function, we introduce some additional notation. We consider a dataset that includes $N$ individuals, with individual $i(i=1, . . N)$ experiencing $J_{i}$ benefit spells in the time period under investigation. The dummy value $c_{i j}^{u}$ indicates if the benefit spell $t_{i j}$ ends with and exit from SA. Analogously, $t_{p, i j}$ denotes the corresponding spell until the receipt of a debt program offer and the dummy value $c_{i j}^{p}$ denotes whether a debt program offer is 
received. For $c_{i j}^{p}=1$, we observe the probability of acceptance, or not. ${ }^{12}$ This yields the following individual likelihood contribution, conditional on unobserved effects $v_{u}, v_{p}$ and $v_{d}$ :

$$
\begin{aligned}
\mathcal{L}_{i}^{k}=\prod_{j=1}^{J_{i}} \theta_{u} & \left(t_{i j} \mid x_{i j}, \tau_{0, i j}, d_{i j}, t_{s, i j}, t_{c, i j}, v_{u}^{k}\right)^{c_{i j}^{u}} \exp \left(-\int_{0}^{t_{i j}} \theta_{u}\left(t_{i j} \mid x_{i j}, \tau_{0, i j}, d_{i j}, t_{s, i j}, t_{c, i j}, v_{u}^{k}\right) d t\right) \\
& \times \theta_{p}\left(t_{p, i j} \mid x_{i j}, \tau_{0, i j}, v_{s}^{k}\right)^{c_{i j}^{p}} \exp \left(-\int_{0}^{t_{p, i j}} \theta_{p}\left(t_{p, i j} \mid x_{i j}, \tau_{0, i j}, v_{s}^{k}\right) d t\right) \\
& \times\left(P_{d}\left(d_{i j} \mid x_{i j}, v_{d}^{k}\right)^{I\left(d_{i j}=1\right)}\left(1-P_{d}\left(d_{i j} \mid x_{i j}, v_{d}^{k}\right)\right)^{I\left(d_{i j}=0\right)}\right)^{c_{i j}^{p}}
\end{aligned}
$$

with $k=1, . . K$ and $i=1, . . N$. Note that this likelihood function imposes that all spells of one individual share the same unobserved heterogeneity term. To obtain the total log likelihood that should be maximized, equation [4a] is integrated over the distribution of mass points weights of $v_{u}, v_{p}$ and $v_{d}$, and subsequently summed over individuals: ${ }^{13}$

$$
\mathcal{L}=\sum_{i=1}^{N} \log \left\{\sum_{k=1}^{K} p^{k} \mathcal{L}_{i}^{k}\right\}
$$

In what follows, we start by maximizing equation [4] with respect to all unknown parameters. To gain more insight in the nature of the debt program effects, we subsequently distinguish between exit out of the SA scheme into employment and exit for other reasons. This means we extend the

\footnotetext{
${ }^{12}$ Although the dummy value of program participation is indexed with ' $\mathrm{ij}$ ', this value is observed only once per individual at maximum.

${ }^{13}$ We derive the number of mass points $K$ by performing likelihood ratio tests.
} 
model with competing risks structure for the exit out of SA, allowing both risks to be correlated to each other and the other two processes. 


\section{ESTIMATION RESULTS}

\subsection{Main results: the benchmark model}

This section describes the estimation results of equations [1], [2] and [3]. Table 3 presents the parameter estimates for the SA exit rate, the debt program offer rate, and the conditional probability of starting an individual debt program. For the distribution of unobserved effects that connects the three processes we find three mass points at maximum, with probability weights that are equal to $26 \%, 2 \%$, and $72 \%$. For the first group, the SA exit rate is low and the debt program offer rate is high. In contrast, the second group - with the smallest probability weight - has unobserved characteristics that are associated with a high SA exit rate and a hazard rate of debt program offers that is equal to zero. Finally, the largest group can be considered as the remaining 'average' category of individuals in our sample. Overall, SA exit rates and debt program offer rates thus are negatively correlated.

Regarding the effect of the debt program on the SA exit rates, we find positive and significant effects for all our three parameters of interest. First, for those individuals that participated the exit rate already has an impact during the program, amounting to about $23 \%(=$ $\exp (0.208)-1)$. This suggests that lock-in effects were not important. Second, after finishing the debt program the effect even doubles to $51 \%(=\exp (0.414)-1)$. Third, for individuals that were targeted but did not participate we also find the impact is substantial $(39 \%=\exp (0.330)-1)$. This suggests these individuals were subsequently confronted with sanctions and increased monitoring. Similar to the literature of threat effects, this can then be interpreted as 'ex post', or unanticipated effects.

As to the other covariates, the age of individuals is the most prominent determinant in all three model outcomes. Both the SA exit rate and the debt program offer arrival rate strongly 
decrease with age, whereas younger individuals are much less likely to show up at the start of the debt program. This indicates that the debt program was mainly targeted at younger clients, but particularly this group that was not very willing to participate. We find a similar pattern for individuals that participate in a work program that is unpaid, i.e. they have higher SA exit rates, are more likely to be targeted at, but less likely to accept the offer. The SA exit rate is relatively low for women, for single households with kids, couples without kids, and individuals with a low education level and bad job prospects. The likelihood of receiving a debt program offer is particularly high among men, single households, and individuals with bad job prospects. SA exit rates increased as from 2010, reflecting the increased sanctioning and monitoring activities that started in these years (DWI 2010). Finally, we find the pattern of duration dependence of the SA exit rate is hump shaped, reflecting the fact that many of the SA benefit spells ended for other reasons than work resumption.

\subsection{Work resumption or out of the labor market?}

With debt program effects that are substantial and significant, the question arises for what reasons individuals left the SA benefit scheme. We stated earlier that caseworkers of the social benefit administration did not register the reasons for $29 \%$ of the SA exits in our sample. As a result, the share of individuals that is reported to have exited into work is likely to be underreported and, consequently, the share of exits out of the labor force probably over reported. Assuming that the degree of underreporting is exogenous, this means that size effect estimates on the exit rate into work will be underestimated as well. ${ }^{14}$ Based upon the analysis of Kok et al. (2008), we

\footnotetext{
${ }^{14}$ If the underreporting of exits into work is correlated, the MPH structure of our model still may well take account of this. As Lancaster (1990) argues, measurement errors in durations can be controlled for by including unobserved effects. The intuition is that individuals may have unobserved characteristics that make them more or less likely to have their exit status reported.
} 
conjecture that the real percentage must be around $40 \%$. From this, we infer that any biases in the size of coefficient impact is probably limited.

Table 4 reports the estimation results for the competing risks model with exits into work and out of the labor force. For expositional reasons, we only focus on the model outcomes for the SA exit rates. For program participants, the effects during and after the provision of debt services do not differ markedly for the exit rates into work and out of the labor force. This suggests that some clients benefitted from the program by exiting to formal jobs. At the same time, it is likely that program participants experienced disutility from the program and exited out of the labor force. They may have responded to this by increasing their search activities and withdrawing from the labor market (voluntarily or involuntarily). These findings are in line with the recent work of Arni et al. (2013), who argue that the individuals that are sanctioned of monitored have an increased willingness to leave the formal labor market and 'gain' more time for job search. The increased out of the labor force exits for program participants persist after program completion. Presumably, public caseworkers had a continued interest in the job search activities and the financial conditions of individuals that were targeted (see also Subsection 4.4).

Turning to the targeted group of individuals that did not participate, there is strong evidence for the presence of threat effects. In contrast to program participants, the increase in the exit rate for this groups is fully confined to an increase in exits out of the labor force. This raises the question whether these transitions are transitory - with many individuals re-entering into the SA scheme after a while - or lead to permanent exits. We return to this issue in section 4.5 , when assessing the costs and benefits of the program.

To gain more insight in the size of effect estimates, Table 5 shows the simulated effect of a debt program intervention that starts in the second month of the SA benefit spell and ends ten months after the start of the SA benefit spell. This simulation resembles the average timing and 
the average length of debt program spells in our data. Table 5 also displays the threat and sanctioning effects for targeted individuals that do not participate in the debt program. Similar to the group of participants in the simulation, we assume that this group is offered a debt program two months after the start of an SA spell. We calculate the increase in the exit probability for the full sample of individuals in our sample, both one year after the start of the SA spell and two years after the start of the SA spell. ${ }^{15}$

The simulations show that the impact of the debt program was substantial, particularly compared to the average baseline exit rate of individuals that is equal to $36 \%$. This result holds both for participants and the targeted individuals that did not show up at the start of the program. For debt program participants we find an impact in the total exit rate after two years that is equal to 8.2 percentage point; for the group of no-shows it amounts to 7.7 percentage point. Moreover, 6.2 percentage point of the total effect of program participation comes from exits out of the labor force. Expressed as a share of the total effect, this effect is comparable to the average share of exits out of the labor force for the full sample of targeted SA recipients that exited out of the labor force. The increase among the no-shows is fully confined to a higher exit rate out of the labor market. Taken together, we conclude that the overall, weighted effect of the debt program both for the participants and the no-shows - mainly originated from the threat of increasing monitoring and/or the imposition of sanctions.

\subsection{Heterogeneous effects}

So far, we have analyzed the impact the debt program had on the overall sample of clients. To get a more precise view in the origins of these effects, we exploit some of the compositional

\footnotetext{
${ }^{15}$ We also calculated simulation outcomes only for the sample of 'treated' individuals that received a debt program offer. This yielded outcomes that did not differ markedly from those for the full sample.
} 
differences in our sample. Individual differences in the size of debts or differences in preferences towards the debt programs may explain the effectiveness of the debt program, as well as the increased exits out of the labor force we find. We thus re-estimate the competing risks model with interaction effects for several stratification levels in our data. Panel A of Table 6 presents the resulting coefficient estimates that are stratified according to age (younger or older than 30), gender, the profiling assessment of job prospects and the education level (more or less than 11 years of education). In the table, the asterisk “*” indicates whether this stratification yields effect estimates that differ between groups, with a significance level of 5\%.

As Table 6 shows, heterogeneous effects are mainly relevant for program participation effects on the exit rate to work. Specifically, debt program effects on the re-employment rate are relatively high among male individuals that are older than 30 , having bad job prospects and a low education level. Generally, these findings are in line with economic intuition, suggesting the restructuring of debts is most valuable - and therefore incentive enhancing - for individuals with higher debts or a low earnings capacity to repay debts. This particularly concerns older, single male individuals with high debt levels, for whom the impediment for work resumption will be high and without a potential partner to repay some of their debts. Also, individuals with low education levels and bad job prospects generally have low earning capacities, rendering it less likely that work resumption substantially increases their chances of repayment.

Turning to remaining effect estimates of the debts program, we generally find no differences in effects between groups that are stratified. Threat effect estimates for no-shows do not vary between the groups, holding both for the exits into work and the exits out of the labor market. Likewise, program participants exit equally fast into non-employment in almost all groups that are considered. It is only for the individuals that are older than 30 that this effect is statistically insignificant. This suggests that younger individuals either experience a relatively 
high disutility from program participation, have higher discount rates or consider it more likely that they will repay their debts in the future.

\subsection{Persistency of effects}

Our results suggest that debt program effects were important, but were largely confined to exits out of the labor market. These effects occurred both among program participants and no-shows. To investigate whether there are any time patterns in these effects, Panel B of Table 6 shows coefficient effect estimates that are allowed to vary over time. For to the debt programs of participants, we specify an additional effect six months after program completion as an interaction dummy. As the table shows, the increase in the work resumption rate of this group is confined to the period of six months, suggesting that this effect is largely transitory. In contrast, the short and long term effects of program participation on exits out of the labor force are equally important.

For the sample of no-shows we included an interaction effect for the threat effects to start six months after the debt program should have started. The effect on work resumption in the first six months is borderline significant $(\mathrm{P}=0.068)$; the effect thereafter is insignificant. Additionally, both the short and long term effect on exits out of the labor force are significant and sizeable. This suggests that threat effects for the no-shows were persistent. Presumably public caseworkers had a continued interest in the full group of individuals that was targeted and were more strict in adhering to the rules for them as well. Many individuals did not feel at ease with this and became more likely to leave the scheme. This finding is in line with Van den Berg et al. (2012), who analyze the impact and persistency of meetings with caseworkers. 


\subsection{Costs and benefits analysis}

Although the debt program was effective in increasing the exit from SA, one may well argue that SA benefit savings of the debt program were not substantial. ${ }^{16}$ With SA recipients that return quickly to the SA scheme, the benefit savings will be of a transitory nature (see also Arni et al. 2013). When calculating the return rates of former SA recipients, this notion seems to be confirmed (see Figure A.1 in the appendix). In particular, about 30\% of former SA recipients that have been offered a debt program re-enter into the scheme after one year, compared to $23 \%$ for the rest of the sample.

To get an idea of the importance of the importance of SA return rates, Table 7 presents the estimated costs and benefit savings that follow from our model outcomes and some additional institutional settings. To calculate benefit savings, we set the benefit level equal to 1,000 euros per month. We distinguish between the effects on program participants and individuals that did not show up at the start of the program. As the accumulated costs and benefits may well change over time, we use different time windows in our analysis - with four years at maximum. For each time window we calculate the number of weeks that are gained by the increased exit rate, as well as the concerning benefit savings. ${ }^{17}$ The resulting outcomes show that the benefit savings were sufficient to achieve cost-effectiveness of the debts program. For program participants it takes two years for the program costs - which where 1,654 euro per person - to be compensated by SA benefit savings. Offering debt programs to the no shows - which involved no program costs -

\footnotetext{
${ }^{16}$ In addition to this, one finding in the literature is that threat effects may shorten subsequent employment or nonparticipation durations for the deadweight of individuals that would have exited also without the program intervention (Arni et al 2013; Van den Berg and Vikstrom 2009).

17 For this purpose, we derive the expected duration until re-entering the SA scheme, conditional on the maximum time window that is used. We multiply this duration with the estimated increase in the exit rate (see Table 6).
} 
was obviously more beneficial. Due to the relatively high return probabilities of this group, however, the benefit savings were smaller than for program participants.

\subsection{What explains our results?}

According to our results, the overall effect of the Priority Care Debt Services on the SA exit rates was positive. Compared to the average baseline exit rate of $36 \%$ that is observed for SA recipients two years after the start of an SA spell, an increase of $10 \%$ percentage point two years after the start of de debt program is substantial. For some part, this result is in line with standard economic predictions, e.g. the settlement of claims probably stimulated individuals to search for work more actively for work. We also find evidence that the debt program was most effective for program participants for which the initial rewards of work resumption were relatively low - with high debts and a low earnings capacity - thus having large potential gains from participating in the program.

For another part, however, our outcomes are less clear-cut. The increase in the SA exit rate that was caused by the debt program predominantly concerned individuals that left the labor force and did not resume work. Moreover, about one third of the targeted group did not start the program. This may seem puzzling at first sight. Program participation had the potential to substantially reduce the debt problems individuals were faced with. Leaving the labor market without SA benefits - would probably worsen debt problems.

One obvious explanation for this finding is that many individuals did not like to participate in the debts program in the first place. As for debt services, disutility as a barrier to program participation may be relevant too. In this respect, Rahim and Arthur (2012) distinguish

three motives: (i) practical issues, such as time and travel costs; (ii) negative perceptions of the helpfulness of debt services; and (iii) personal and psychological issues such as depression, 
anxiety or embarrassment. Within the context of the current analysis, an additional explanation is that providing full transparency on financial conditions inhibited the risk of fraud detection. A more recent phenomenon in this literature is that threat effects due to increased counseling and monitoring may impact the inflow into non-participation - see Hagglund (2006), Arni et al. (2013) and Cocks et al (2013). This suggests that individuals derive a disutility from such activities which is sufficiently large to leave unemployment schemes without work resumption.

Zooming into the specific context of the current analysis, threat effects were especially relevant for the targeted group of SA recipients with debt problems. It is likely that these individuals had high discount rates and undervalued the potential gains of the debt program. They may also have been susceptive to hyperbolic discounting. Della Vigna and Paserman (2005) argue that impatient individuals search less intensively and set lower reservation wages. With hyperbolic time preferences the search effect dominates and increases in impatience lead to lower job-finding rates. Within the context of the debt program that was offered, the implications of hyperbolic discounting are as follows. Assuming that the program decreased the utility individuals derived from the SA benefit scheme, impatient individuals responded by increasing their search intensity and decreasing their reservation wage. As to the first effect, the response was probably small, with increases in the future utility due to work resumption that were highly discounted. Impatient individuals may therefore have responded more directly by lowering their reservation wages instead. For decreases of the reservation wage that were sufficiently large, the value function of receiving SA benefits may even have dropped below the value of nonparticipation. Taken together, impatient individuals that disliked the program thus were more likely to leave the labor market than patient ones, while increasing their work resumption rates only to a limited extent. Both of these predictions are in line with our estimation results. 


\section{CONCLUSION}

In this paper we studied the effectiveness of an intervention that was targeted at a specific group of Dutch SA recipients with debt problems that lived in the city of Amsterdam. Individuals were assisted in the restructuring of debts, alerted on their entitlement to income supplements, and training programs were offered to improve their budgeting skills and financial literacy. The idea was that the restructuring of debts would remove an important impediment for work resumption. Without any informal settlement of claims, additional earnings of the targeted group would largely be transferred to creditors.

Our main finding is that the debt services increased the exit out of SA, but only a small part of the effects can be attributed to increased work resumption of program participants. Moreover, about one third of targeted individuals did not participate in the debt program. This suggests that many participants perceived or experienced the program as unpleasant and responded in different ways to this. Targeted individuals that did not start the program had substantially higher exit rates into non-participation, indicating they responded to increased monitoring and sanctioning of their caseworkers. At the same time, program participants also showed an increase in the rate of leaving the labor force. Presumably, some participants - mostly below the age of 30 - did not like continued program participation and therefore opted to leave the SA scheme to avoid further meetings. These effects are persistent over time.

With this in mind, the policy implications of this study are not so clear-cut. From the perspective of the benefit administration, the debt program was cost-effective for both the group of program participants and the group of the no-shows. We also find particularly older SA clients benefit from the program - with higher work resumption rates and no significant increases in the exit rate out of the labor force. The debt program thus appears to be a useful intervention for 
some part of the targeted group. That said, many individuals that were targeted probably disliked participation in the program, the increased monitoring and sanctioning activities and the income losses if they left the labor market. Clearly, bringing these individuals back to work is not an easy task. It largely depends on the normative judgment of policymakers how - and at what costs these should be forced into the right track to work. 


\section{REFERENCES}

Abbring J.H., Van den Berg G.J. (2003) The non-parametric identification of treatment effects in duration models, Econometrica, 71(5): 1491-1517.

Abbring J.H., Van den Berg G.J., Van Ours, J.C. (2005) The effect of unemployment insurance sanctions on the transition rate from unemployment to employment, The Economic Journal, 115(505): 602630.

Andersen, S.H. (2013) How scary is it? - Review of literature on the threat effect of active labor market programs, The Rockwool Foundation Research Unit, Study Paper No. 48

Arni P., Lalive R., Van Ours J.C. (2013) How effective are unemployment benefit sanctions? Looking beyond unemployment exit, Journal of Applied Economics, forthcoming.

Berg, G.J. van den, Kjaersgaard, L, Rosholm, M. (2012) To Meet or Not to Meet (Your Case Worker) that is the question, IZA Discussion paper 6476, IZA: Bonn.

Boockmann B., Thomsen S.L., Walter T. (2009) Intensifying the use of benefit sanctions: an effective tool to shorten welfare receipt and speed up transitions to employment? Discussion Paper 4580, IZA, Bonn.

Card D., Kluve J., Weber A. (2010) Active labor market policy evaluations: a meta-analysis, The Economic Journal, 120: F452-F477.

Cockx, B., Ghirelli, C., Van der Linden, B. (2013) Monitoring Job Search Effort with Hyperbolic Time Preferences and Non-Compliance: A Welfare Analysis, IZA Discussion Paper 7266.

Della Vigna S., Paserman M.D. (2005) Job search and impatience, Journal of Labor Economics, 23(3): $527-588$.

DWI Amsterdam (2008) Voorrangszorg schuldhulpverlening. Juni 2008, Gemeente Amsterdam.

DWI Amsterdam (2010) Meedoen en meewerken. September 2010, Gemeente Amsterdam.

Faber, R., Koning, P. (2012) Why Not Fully Spend a Conditional Block Grant?, IZA Discussion Papers 6712, Institute for the Study of Labor (IZA).

Frijters, P., Klaauw, B. van der (2006) Job Search with Nonparticipation, Economic Journal, 116(508), 45-83.

Geerdsen, L.P. (2006) Is there a Threat Effect of Labour Market Programmes? A Study of ALMP in the Danish UI System, The Economic Journal, 116(513): 738-750.

Graversen, B.K., Van Ours, J.C. (2008) How to help unemployed find jobs quickly: Experimental evidence from a mandatory activation program, Journal of Public Economics, 92(10-11): 20202035. 
Hagglund, P. (2006) Are there pre-programme effects of Swedish active labour market policies? Evidence from three randomised experiments, IFAU Working paper 2006:2.

Han, S., Li, W. (2007). Fresh start or head start? The effect of filing for personal bankruptcy on work effort, Journal of Financial Services Research, 31(2-3):123-52.

Heckman, J.J., Moon, S.H., Pinto, R., Yavitz, A.Q. (2010) The Rate of Return to the High Scope Perry Preschool Program, Journal of Public Economics, 94(1-2): 114-128.

Heckman, J.J., Kautz, T.D. (2012), Hard Evidence on Soft Skills, NBER Working paper series, Working paper 18121.

Jensen P., Svarer M., Rosholm M. (2003) The response of youth unemployment to benefits, incentives, and sanctions, European Journal of Political Economy, 19(2): 301-316.

Kok, L., Hop. P., Alla, A. (2008) Van bijstand naar werk in Amsterdam: update. Effectiviteit van reintegratietrajecten voor bijstandsgerechtigden in de periode 2001-2007, SEO rapport 2008-52.

Kluve J. (2010) The effectiveness of European active labor market programs, Labour Economics, 17(6): 904-918.

Lalive R., Van Ours J.C., Zweimuller J. (2005) The effect of benefit sanctions on the duration of unemployment, Journal of the European Economic Association, 3(6): 1386-1417.

Lancaster, T. (1990) The Econometric Analysis of Transition Data, Cambridge University Press: Brown University.

Paserman M.D. (2008) Job search and hyperbolic discounting: structural estimation and policy evaluation, The Economic Journal, 118(531): 1418-1452.

Rahim, N., Arthur S. (2012) Experiences of Debt and Debt Advice Services in Islington. Final Report, National Centre for Social Research.

Rosholm M., Svarer, M. (2008) The Threat Effect of Active Labour Market Programmes, Scandinavian Journal of Economics, 110(2): 385-401.

Van der Klaauw B., Kastoryano, S. (2011) Dynamic Evaluation of Job Search Assistance, IZA Discussion paper 5424, IZA Institute for the Study of Labor (IZA).

Van der Klaauw B., Van Ours J.C. (2013) Carrot and stick: how reemployment bonuses and benefit sanctions affect job finding rates, Journal of Applied Econometrics, 28: 275-296.

White, M. (2011), Corporate and Personal Bankruptcy Law, Annual Review of Law and Social Science, 7 : $139-164$ 
Table 1: Sample statistics of social assistance recipients in Amsterdam (2008-2012); "**" indicates that the difference of with the full sample average is significant at $5 \%$

\begin{tabular}{|c|c|c|c|c|c|c|}
\hline & \multicolumn{2}{|c|}{ Full sample } & \multicolumn{4}{|c|}{ Sample with Debt services ${ }^{\text {a }}$} \\
\hline & & & $\begin{array}{l}\text { Program } \\
\text { offer }\end{array}$ & $\begin{array}{l}\text { Program } \\
\text { Started } \\
\end{array}$ & $\begin{array}{l}\text { Program } \\
\text { Completed }\end{array}$ & $\begin{array}{l}\text { Start formal } \\
\text { Debt program }\end{array}$ \\
\hline Age & 37.6 & $(0.068)$ & $33.7 *$ & $34.4 *$ & $34.7 *$ & 38.7 \\
\hline Women & 0.39 & $(0.0028)$ & $0.35 *$ & 0.38 & 0.38 & $0.45^{*}$ \\
\hline Work program (fraction) & 0.17 & $(0.0022)$ & $0.29 *$ & $0.26 *$ & $0.24 *$ & $0.13^{*}$ \\
\hline Education years & 10.4 & $(0.013)$ & $10.2 *$ & $10.2 *$ & $10.1^{*}$ & $10.1^{*}$ \\
\hline Education completed (last year) & 0.81 & $(0.0022)$ & $0.78 *$ & $0.78 *$ & $0.77 *$ & 0.80 \\
\hline \multicolumn{7}{|l|}{ Household status (fractions) } \\
\hline Single, no kids & 0.75 & $(0.0025)$ & 0.76 & 0.75 & 0.74 & 0.73 \\
\hline Single, with kids & 0.17 & $(0.0022)$ & $0.19 *$ & $0.20 *$ & $0.20 *$ & $0.22 *$ \\
\hline Couple, no kids & 0.055 & $(0.0013)$ & $0.037 *$ & $0.035^{*}$ & $0.038^{*}$ & $0.030 *$ \\
\hline Couple, with kids & 0.033 & $(0.0011)$ & $0.017^{*}$ & $0.018^{*}$ & $0.014 *$ & $0.020 *$ \\
\hline \multicolumn{7}{|l|}{ Profiling categories (fractions) } \\
\hline 1: "No social contacts, no job skills" & 0.17 & $(0.0022)$ & $0.15^{*}$ & $0.15^{*}$ & $0.15^{*}$ & 0.20 \\
\hline 2: "Social contacts, no job skills" & 0.30 & $(0.0027)$ & $0.33 *$ & $0.34 *$ & $0.35^{*}$ & $0.35^{*}$ \\
\hline 3: "Social activities, no job skills" & 0.25 & $(0.0025)$ & $0.35^{*}$ & $0.35^{*}$ & $0.35 *$ & $0.33^{*}$ \\
\hline 4: "Mediation needed; job skills" & 0.20 & $(0.0023)$ & $0.14 *$ & $0.13^{*}$ & $0.12 *$ & $0.10 *$ \\
\hline 5: "Able to find work" & 0.027 & $(0.00094)$ & $0.015 *$ & $0.016 *$ & $0.014 *$ & 0.018 \\
\hline Unknown & 0.048 & $(0.0012)$ & $0.022 *$ & $0.017 *$ & $0.015 *$ & $0.0090 *$ \\
\hline \multicolumn{7}{|l|}{ Year of inflow (fractions) } \\
\hline 2008 & 0.048 & $(0.0012)$ & $0.053 *$ & $0.058 *$ & $0.068 *$ & $0.11 *$ \\
\hline 2009 & 0.30 & $(0.0026)$ & $0.36 *$ & $0.37 *$ & $0.36^{*}$ & $0.40 *$ \\
\hline 2010 & 0.35 & $(0.0028)$ & $0.40 *$ & $0.38 *$ & 0.35 & 0.37 \\
\hline 2011 & 0.31 & $(0.0027)$ & $0.19 *$ & $0.19 *$ & $0.22 *$ & $0.12 *$ \\
\hline Completed durations length & 328.7 & $(2.31)$ & $376.9 *$ & $408.3 *$ & $471.2 *$ & $448.4^{*}$ \\
\hline Fraction durations right censored & 0.58 & $(0.0029)$ & $0.54 *$ & $0.59 *$ & $0.69 *$ & $0.73 *$ \\
\hline Fraction inflow into work & 0.30 & $(0.0041)$ & $0.20 *$ & $0.22 *$ & $0.20 *$ & 0.29 \\
\hline \# Observations & 29,885 & & 2,940 & 1,944 & 1,314 & 334 \\
\hline
\end{tabular}


Table 2: OLS regression on debt value on subsample of debt program participants $(2008-2012)^{a b}$

\author{
Debt value
}

(x 1,000 euro)

\title{
Age category
}

Age 25-34

$6.12 * *$

Age 35-44

$14.16 * * *$

Age 45-54

$15.76 * * *$

Age 55-65

$16.96 * * *$

Women

$-1.78$

Work program participant

$-6.59 * * *$

Education years

$1.14 * *$

Education completed (last year)

0.85

F-test on household type dummies

0.62

$\mathrm{P}=0.60$

F-test on profiling category dummies

0.74

$\mathrm{P}=0.59$

F-test on year of inflow in program

0.81

$\mathrm{P}=0.49$

Constant

$-2.51$

(7.20)

\# Observations

1,710

R-squared

0.070

\footnotetext{
${ }^{a}$ Note that the statistics of the subsample of individuals with debt services are based on their first SA benefit spell only. In this way, we avoid the overrepresentation of clients with multiple SA benefit spells.

$\mathrm{b} * * * / * * / *$ indicate significance at $\mathrm{P}=1 \% / 5 \% / 10 \%$, respectively.
} 
Table 3: Maximum Likelihood Estimates of baseline model $(\log$ likelihood $=117,512)$

\begin{tabular}{|c|c|c|c|c|c|c|}
\hline \multirow[b]{2}{*}{ Unobserved heterogeneity } & \multicolumn{2}{|c|}{ SA exit rate } & \multicolumn{2}{|c|}{$\begin{array}{c}\text { Debt program } \\
\text { offer rate }\end{array}$} & \multicolumn{2}{|c|}{$\begin{array}{l}\text { Offer acceptance } \\
\text { probability }\end{array}$} \\
\hline & & & & & & \\
\hline$v_{1}(=$ constant $)$ & -9.509 & $(0.190)$ & -5.713 & $(0.200)$ & 0.324 & $(0.360)$ \\
\hline$v_{2}$ & 3.452 & $(0.363)$ & $-\infty$ & & . & \\
\hline$v_{3}$ & 2.016 & $(0.141)$ & -0.808 & $(0.129)$ & -0.421 & $(0.220)$ \\
\hline$p_{1}$ & 0.264 & $(0.027)$ & & & & \\
\hline $\begin{array}{l}P T \\
p_{2}\end{array}$ & 0.018 & $(0.014)$ & & & & \\
\hline$p_{3}$ & 0.717 & $(0.031)$ & & & & \\
\hline \multicolumn{7}{|l|}{ Debt program effects } \\
\hline Effect during program & 0.208 & $(0.073)$ & & & & \\
\hline Effect after program & 0.415 & $(0.072)$ & & & & \\
\hline Threat effect no-shows & 0.330 & $(0.071)$ & & & & \\
\hline \multicolumn{7}{|l|}{ Covariate effects } \\
\hline \multicolumn{7}{|l|}{ Age $<25$ (reference) } \\
\hline Age $25-34$ & -0.496 & $(0.033)$ & 0.010 & $(0.072)$ & 0.456 & $(0.127)$ \\
\hline Age $35-44$ & -0.917 & $(0.038)$ & -0.208 & $(0.086)$ & 0.500 & $(0.158)$ \\
\hline Age $45-54$ & -1.193 & $(0.041)$ & -0.444 & $(0.092)$ & 0.649 & $(0.169)$ \\
\hline Age $55-65$ & -1.399 & $(0.051)$ & -0.934 & $(0.126)$ & 0.614 & $(0.246)$ \\
\hline Women & -0.084 & $(0.026)$ & -0.184 & $(0.062)$ & 0.379 & $(0.119)$ \\
\hline Work program participant & 0.611 & $(0.031)$ & 0.119 & $(0.064)$ & -0.226 & $(0.120)$ \\
\hline Education years & 0.029 & $(0.005)$ & -0.021 & $(0.015)$ & -0.039 & $(0.028)$ \\
\hline Last education completed & -0.001 & $(0.030)$ & -0.120 & $(0.063)$ & 0.168 & $(0.116)$ \\
\hline \multicolumn{7}{|l|}{ Single, no kids (reference) } \\
\hline Single, kids & -0.450 & $(0.036)$ & 0.165 & $(0.078)$ & 0.010 & $(0.148)$ \\
\hline Couple, no kids & -0.179 & $(0.049)$ & -0.254 & $(0.121)$ & -0.288 & $(0.217)$ \\
\hline Couple, kids & 0.062 & $(0.059)$ & -0.415 & $(0.167)$ & 0.246 & $(0.342)$ \\
\hline \multicolumn{7}{|l|}{ Profiling category 1 (ref.) } \\
\hline Profiling category 2 & 0.043 & $(0.036)$ & 0.064 & $(0.074)$ & 0.095 & $(0.141)$ \\
\hline Profiling category 3 & 0.226 & $(0.037)$ & 0.190 & $(0.075)$ & 0.065 & $(0.142)$ \\
\hline Profiling category 4 & 1.008 & $(0.038)$ & -0.344 & $(0.091)$ & 0.118 & $(0.172)$ \\
\hline Profiling category 5 & 0.387 & $(0.072)$ & -0.397 & $(0.186)$ & 0.200 & $(0.371)$ \\
\hline Profiling category unknown & 1.291 & $(0.052)$ & -0.671 & $(0.164)$ & -0.589 & $(0.302)$ \\
\hline \multicolumn{7}{|l|}{ Calendar time effects } \\
\hline 2010 & 0.417 & $(0.026)$ & -0.204 & $(0.059)$ & -0.074 & $(0.111)$ \\
\hline $2011 / 2012$ & 0.347 & $(0.033)$ & -1.862 & $(0.078)$ & 0.128 & $(0.144)$ \\
\hline \multicolumn{7}{|l|}{ Duration dependence } \\
\hline \multicolumn{7}{|l|}{1 month (reference) } \\
\hline $2-3$ months & 0.279 & $(0.043)$ & -0.777 & $(0.074)$ & 0.188 & $(0.166)$ \\
\hline 4-6 months & 0.376 & $(0.040)$ & -1.044 & $(0.068)$ & 0.290 & $(0.144)$ \\
\hline 7-12 months & 0.473 & $(0.040)$ & -1.583 & $(0.070)$ & -0.102 & $(0.144)$ \\
\hline 13-24 months & 0.473 & $(0.045)$ & -2.134 & $(0.081)$ & 0.308 & $(0.160)$ \\
\hline 25-36 months & 0.385 & $(0.057)$ & -3.522 & $(0.183)$ & . & \\
\hline$\geq 37$ months & 0.348 & $(0.101)$ & -5.508 & (1.005) & . & \\
\hline
\end{tabular}


Table 4: Maximum Likelihood Estimates for SA exit rate competing risks model

\begin{tabular}{|c|c|c|c|c|c|c|}
\hline \multirow{2}{*}{ Unobserved heterogeneity } & \multicolumn{2}{|c|}{$\begin{array}{c}\text { SA exit rate: } \\
\text { total }\end{array}$} & \multicolumn{2}{|c|}{$\begin{array}{l}\text { SA exit rate: } \\
\text { work }\end{array}$} & \multicolumn{2}{|c|}{$\begin{array}{c}\text { SA exit rate: } \\
\text { Non-work }\end{array}$} \\
\hline & & & & & & \\
\hline$v_{1}^{u}($ constant $)$ & -9.509 & $(0.190)$ & $-\infty$ & & -10.210 & $(0.629)$ \\
\hline$v_{2}^{u}$ & 3.452 & $(0.363)$ & -8.695 & $(0.181)$ & 3.922 & $(0.630)$ \\
\hline$v_{3}^{u}$ & 2.016 & $(0.141)$ & -10.067 & $(0.158)$ & 2.745 & $(0.581)$ \\
\hline$p_{1}$ & 0.264 & $(0.027)$ & 0.225 & $(0.035)$ & & \\
\hline$p_{2}$ & 0.018 & $(0.014)$ & 0.054 & $(0.024)$ & & \\
\hline$p_{3}$ & 0.717 & $(0.031)$ & 0.720 & $(0.046)$ & & \\
\hline \multicolumn{7}{|l|}{ Debt program effects } \\
\hline Effect during program & 0.208 & $(0.073)$ & 0.233 & $(0.115)$ & 0.244 & $(0.082)$ \\
\hline Effect after program & 0.415 & $(0.072)$ & 0.277 & $(0.120)$ & 0.460 & $(0.080)$ \\
\hline Effect no-shows & 0.330 & $(0.071)$ & -0.013 & $(0.107)$ & 0.386 & $(0.074)$ \\
\hline \multicolumn{7}{|l|}{ Covariate effects } \\
\hline \multicolumn{7}{|l|}{ Age $<25$ (reference) } \\
\hline Age $25-34$ & -0.496 & $(0.033)$ & -0.201 & $(0.059)$ & -0.570 & $(0.037)$ \\
\hline Age $35-44$ & -0.917 & $(0.038)$ & -0.351 & $(0.065)$ & -1.135 & $(0.044)$ \\
\hline Age $45-54$ & -1.193 & $(0.041)$ & -0.614 & $(0.070)$ & -1.391 & $(0.048)$ \\
\hline Age 55-65 & -1.399 & $(0.051)$ & -0.815 & $(0.091)$ & -1.574 & $(0.060)$ \\
\hline Women & -0.084 & $(0.026)$ & 0.001 & $(0.042)$ & -0.122 & $(0.031)$ \\
\hline Work program participant & 0.611 & $(0.031)$ & 0.174 & $(0.050)$ & 0.755 & $(0.036)$ \\
\hline Education years & 0.029 & $(0.005)$ & 0.079 & $(0.008)$ & -0.008 & $(0.007)$ \\
\hline Last education completed & -0.001 & $(0.030)$ & 0.034 & $(0.052)$ & 0.018 & $(0.034)$ \\
\hline \multicolumn{7}{|l|}{ Single, no kids (reference) } \\
\hline Single, kids & -0.450 & $(0.036)$ & -0.553 & $(0.064)$ & -0.403 & $(0.043)$ \\
\hline Couple, no kids & -0.179 & $(0.049)$ & -0.119 & $(0.078)$ & -0.203 & $(0.060)$ \\
\hline Couple, kids & 0.062 & $(0.059)$ & -0.051 & $(0.100)$ & 0.080 & $(0.069)$ \\
\hline \multicolumn{7}{|l|}{ Profiling category 1 (ref.) } \\
\hline Profiling category 2 & 0.043 & $(0.036)$ & 0.212 & $(0.092)$ & -0.002 & $(0.039)$ \\
\hline Profiling category 3 & 0.226 & $(0.037)$ & 1.100 & $(0.086)$ & -0.013 & $(0.041)$ \\
\hline Profiling category 4 & 1.008 & $(0.038)$ & 2.429 & $(0.086)$ & 0.280 & $(0.044)$ \\
\hline Profiling category 5 & 0.387 & $(0.072)$ & 1.620 & $(0.123)$ & -0.089 & $(0.090)$ \\
\hline Profiling category unknown & 1.291 & $(0.052)$ & 2.318 & $(0.098)$ & 0.835 & $(0.060)$ \\
\hline \multicolumn{7}{|l|}{ Calendar time effects } \\
\hline 2010 & 0.417 & $(0.026)$ & 0.252 & $(0.046)$ & 0.455 & $(0.030)$ \\
\hline $2011 / 2012$ & 0.347 & $(0.033)$ & 0.180 & $(0.059)$ & 0.391 & $(0.040)$ \\
\hline \multicolumn{7}{|l|}{ Duration dependence } \\
\hline \multicolumn{7}{|l|}{1 month (reference) } \\
\hline 2-3 months & 0.279 & $(0.043)$ & 0.261 & $(0.065)$ & 0.287 & $(0.058)$ \\
\hline 4-6 months & 0.376 & $(0.040)$ & 0.108 & $(0.062)$ & 0.530 & $(0.051)$ \\
\hline 7-12 months & 0.473 & $(0.040)$ & -0.041 & $(0.064)$ & 0.706 & $(0.050)$ \\
\hline 13-24 months & 0.473 & $(0.045)$ & -0.219 & $(0.071)$ & 0.718 & $(0.054)$ \\
\hline $25-36$ months & 0.385 & $(0.057)$ & -0.413 & $(0.096)$ & 0.624 & $(0.067)$ \\
\hline$\geq 37$ months & 0.348 & $(0.101)$ & -1.144 & $(0.261)$ & 0.728 & (0.110) \\
\hline
\end{tabular}


Table 5: Simulations for the exit rate probability within two years after entering SA (effects in fractions)

\begin{tabular}{llcc}
\hline & $\begin{array}{l}\text { Effect on work } \\
\text { probability }\end{array}$ & $\begin{array}{l}\text { Effect on non- } \\
\text { participation exit } \\
\text { probability }\end{array}$ & Total effect \\
\hline (i) Effect debt program of nine months on participants & & \\
Effect during program & 0.010 & 0.021 & 0.030 \\
Effect after program & 0.010 & 0.041 & 0.052 \\
\hline Total & 0.020 & 0.062 & \\
(ii) Effect debt program offer on no-shows & & & \\
Total effect & & & \\
\hline Total weighted effect & & & \\
\hline
\end{tabular}




\section{Table 6: ML estimates debt program effects with exits as competing risks}

Heterogeneous effects (Panel A) and Persistency effects (Panel B)

\begin{tabular}{|c|c|c|c|c|c|c|}
\hline & \multicolumn{3}{|c|}{ SA exit into work } & \multicolumn{3}{|c|}{ SA exit into non-work } \\
\hline & $\begin{array}{c}\text { Effect } \\
\text { during } \\
\text { program }\end{array}$ & $\begin{array}{c}\text { Effect } \\
\text { after } \\
\text { program }\end{array}$ & $\begin{array}{l}\text { Threat } \\
\text { effect non- } \\
\text { participants }\end{array}$ & $\begin{array}{c}\text { Effect } \\
\text { during } \\
\text { program }\end{array}$ & $\begin{array}{c}\text { Effect } \\
\text { after } \\
\text { program }\end{array}$ & $\begin{array}{c}\text { Threat } \\
\text { effect non- } \\
\text { participants }\end{array}$ \\
\hline Full sample & $\begin{array}{c}0.233 \\
(0.115)\end{array}$ & $\begin{array}{c}0.277 \\
(0.120)\end{array}$ & $\begin{array}{l}-0.013 \\
(0.107)\end{array}$ & $\begin{array}{c}0.224 \\
(0.082)\end{array}$ & $\begin{array}{c}0.460 \\
(0.080)\end{array}$ & $\begin{array}{c}0.386 \\
(0.074)\end{array}$ \\
\hline \multicolumn{7}{|l|}{ Panel A: Heterogeneous effects } \\
\hline Reference: individuals $<30$ years & $\begin{array}{l}-0.071 \\
(0.178)\end{array}$ & $\begin{array}{c}0.204 \\
(0.173)\end{array}$ & $\begin{array}{l}-0.163 \\
(0.149)\end{array}$ & $\begin{array}{c}0.374 \\
(0.096)\end{array}$ & $\begin{array}{c}0.686 \\
(0.094)\end{array}$ & $\begin{array}{c}0.395 \\
(0.089)\end{array}$ \\
\hline Individuals $\geq 30$ years & $\begin{array}{l}0.537 * \\
(0.230)\end{array}$ & $\begin{array}{c}0.144 \\
(0.233)\end{array}$ & $\begin{array}{c}0.325 \\
(0.213)\end{array}$ & $\begin{array}{c}-0.333^{*} \\
(0.140)\end{array}$ & $\begin{array}{c}-0.594^{*} \\
(0.141)\end{array}$ & $\begin{array}{l}-0.010 \\
(0.118)\end{array}$ \\
\hline Reference: Male & $\begin{array}{c}0.375 \\
(0.133)\end{array}$ & $\begin{array}{c}0.453 \\
(0.136)\end{array}$ & $\begin{array}{c}0.001 \\
(0.123)\end{array}$ & $\begin{array}{c}0.299 \\
(0.098)\end{array}$ & $\begin{array}{c}0.490 \\
(0.096)\end{array}$ & $\begin{array}{c}0.387 \\
(0.081)\end{array}$ \\
\hline Female & $\begin{array}{c}-0.458^{*} \\
(0.252)\end{array}$ & $\begin{array}{l}-0.682 * \\
(0.284)\end{array}$ & $\begin{array}{l}-0.042 \\
(0.247)\end{array}$ & $\begin{array}{l}-0.126 \\
(0.139)\end{array}$ & $\begin{array}{l}-0.067 \\
(0.137)\end{array}$ & $\begin{array}{c}0.022 \\
(0.131)\end{array}$ \\
\hline Reference: Job prospects low & $\begin{array}{c}0.248 \\
(0.157)\end{array}$ & $\begin{array}{c}0.473 \\
(0.149)\end{array}$ & $\begin{array}{c}0.160 \\
(0.141)\end{array}$ & $\begin{array}{c}0.223 \\
(0.088)\end{array}$ & $\begin{array}{c}0.510 \\
(0.086)\end{array}$ & $\begin{array}{c}0.432 \\
(0.077)\end{array}$ \\
\hline Reasonable job prospects & $\begin{array}{l}-0.041 \\
(0.226)\end{array}$ & $\begin{array}{c}-0.527^{*} \\
(0.244)\end{array}$ & $\begin{array}{l}-0.398^{*} \\
(0.215)\end{array}$ & $\begin{array}{c}0.104 \\
(0.165)\end{array}$ & $\begin{array}{l}-0.295 \\
(0.174)\end{array}$ & $\begin{array}{l}-0.202 \\
(0.152)\end{array}$ \\
\hline Reference: Education years $<11$ & $\begin{array}{c}0.282 \\
(0.140)\end{array}$ & $\begin{array}{c}0.481 \\
(0.141)\end{array}$ & $\begin{array}{l}-0.182 \\
(0.147)\end{array}$ & $\begin{array}{c}0.236 \\
(0.093)\end{array}$ & $\begin{array}{c}0.394 \\
(0.093)\end{array}$ & $\begin{array}{c}0.401 \\
(0.081)\end{array}$ \\
\hline Education years $\geq 11$ & $\begin{array}{l}-0.141 \\
(0.236)\end{array}$ & $\begin{array}{c}-0.623 * \\
(0.256)\end{array}$ & $\begin{array}{l}0.402 * \\
(0.213)\end{array}$ & $\begin{array}{c}0.036 \\
(0.142)\end{array}$ & $\begin{array}{c}0.197 \\
(0.136)\end{array}$ & $\begin{array}{l}-0.026 \\
(0.136)\end{array}$ \\
\hline \multicolumn{7}{|l|}{ Panel B: Persistency effects } \\
\hline Constant effects (during program) & $\begin{array}{c}0.233 \\
(0.115)\end{array}$ & & & $\begin{array}{c}0.230 \\
(0.081)\end{array}$ & & \\
\hline $\begin{array}{l}\text { Reference: Short run effects }(<6 \\
\text { months) }\end{array}$ & & $\begin{array}{c}0.452 \\
(0.145)\end{array}$ & $\begin{array}{l}-0.212 \\
(0.154)\end{array}$ & & $\begin{array}{c}0.496 \\
(0.093)\end{array}$ & $\begin{array}{c}0.289 \\
(0.084)\end{array}$ \\
\hline Long run effects ( $\geq 6$ months) & & $\begin{array}{l}-0.504^{*} \\
(0.237)\end{array}$ & $\begin{array}{l}0.414^{*} \\
(0.209)\end{array}$ & & $\begin{array}{l}-0.115 \\
(0.118)\end{array}$ & $\begin{array}{l}0.272 * \\
(0.107)\end{array}$ \\
\hline
\end{tabular}


Table 7: Cost and benefit analysis of the debt program per individual (accumulated amounts in euros; SA benefit weeks in brackets)

\begin{tabular}{|c|c|c|c|c|}
\hline & \multicolumn{4}{|c|}{ Time window } \\
\hline & 1 year & 2 years & 3 years & 4 years \\
\hline \multicolumn{5}{|l|}{ Debt program participants } \\
\hline \multirow{2}{*}{$\begin{array}{l}\text { Benefit savings due to higher exit } \\
\text { rate }\end{array}$} & 765 & 1,383 & 1,886 & 2,343 \\
\hline & [ 3.3 weeks] & [ 6.0 weeks ] & [ 8.2 weeks] & [ 10.2 weeks] \\
\hline Costs of debt program & $-/-1,654$ & $-/-1,654$ & $-/-1,654$ & $-/-1,654$ \\
\hline Total & $-/-935$ & $-/-271$ & 232 & 689 \\
\hline \multicolumn{5}{|l|}{ No-shows } \\
\hline \multirow{2}{*}{$\begin{array}{l}\text { Benefit savings due to higher exit } \\
\text { rate }\end{array}$} & 719 & 1,312 & 1,773 & 2,037 \\
\hline & [ 3.1 weeks ] & [ 5.7 weeks ] & [ 7.7 weeks ] & [ 8.8 weeks ] \\
\hline Weighted average of net effect & $-/-386$ & 255 & 746 & 1,141 \\
\hline
\end{tabular}

Notes: the benefit level is set equal to 12,000 euro per year. 


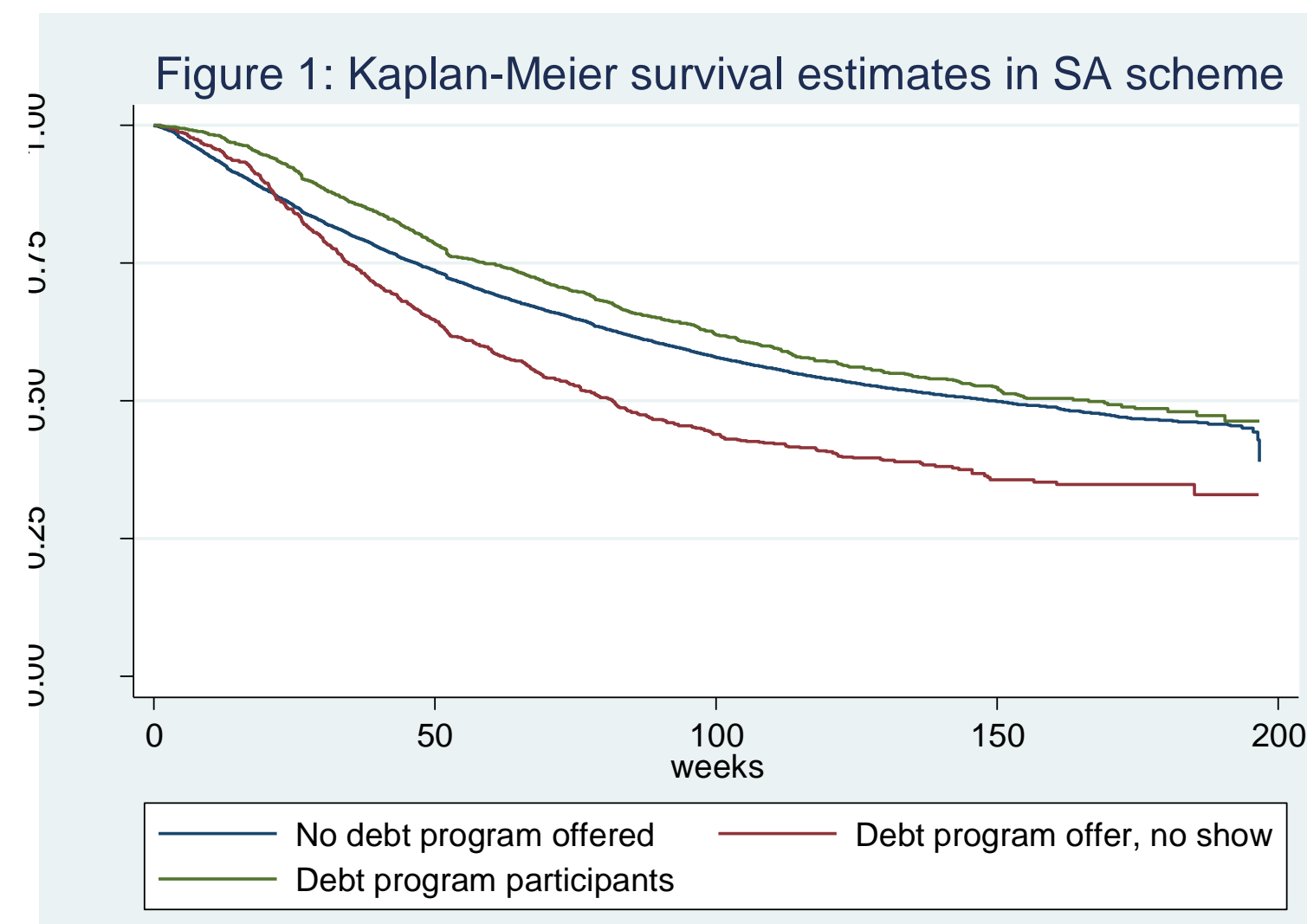


Figure 2A: SA exit rate into work

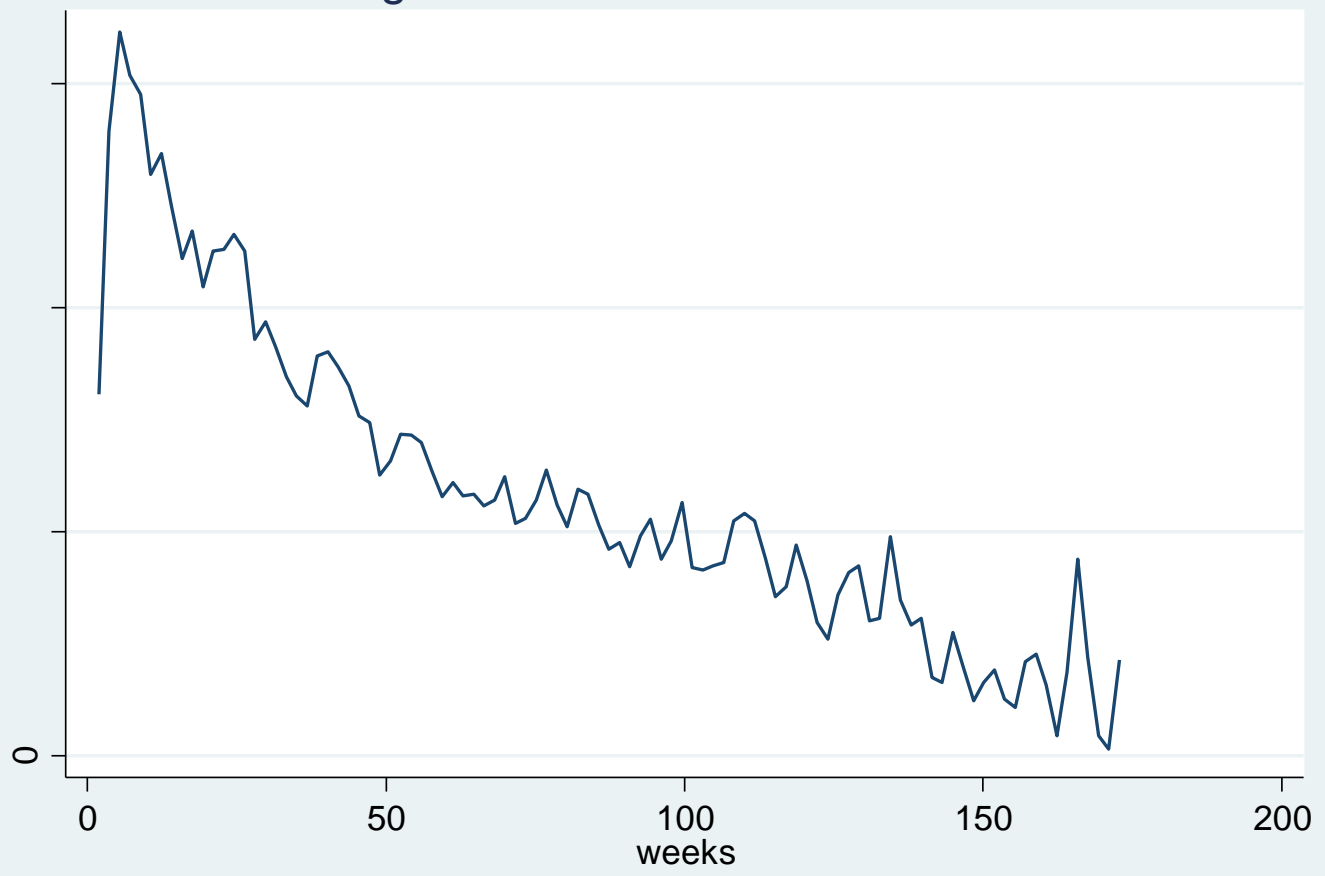

Figure 2B: SA exit rate out of the labor force

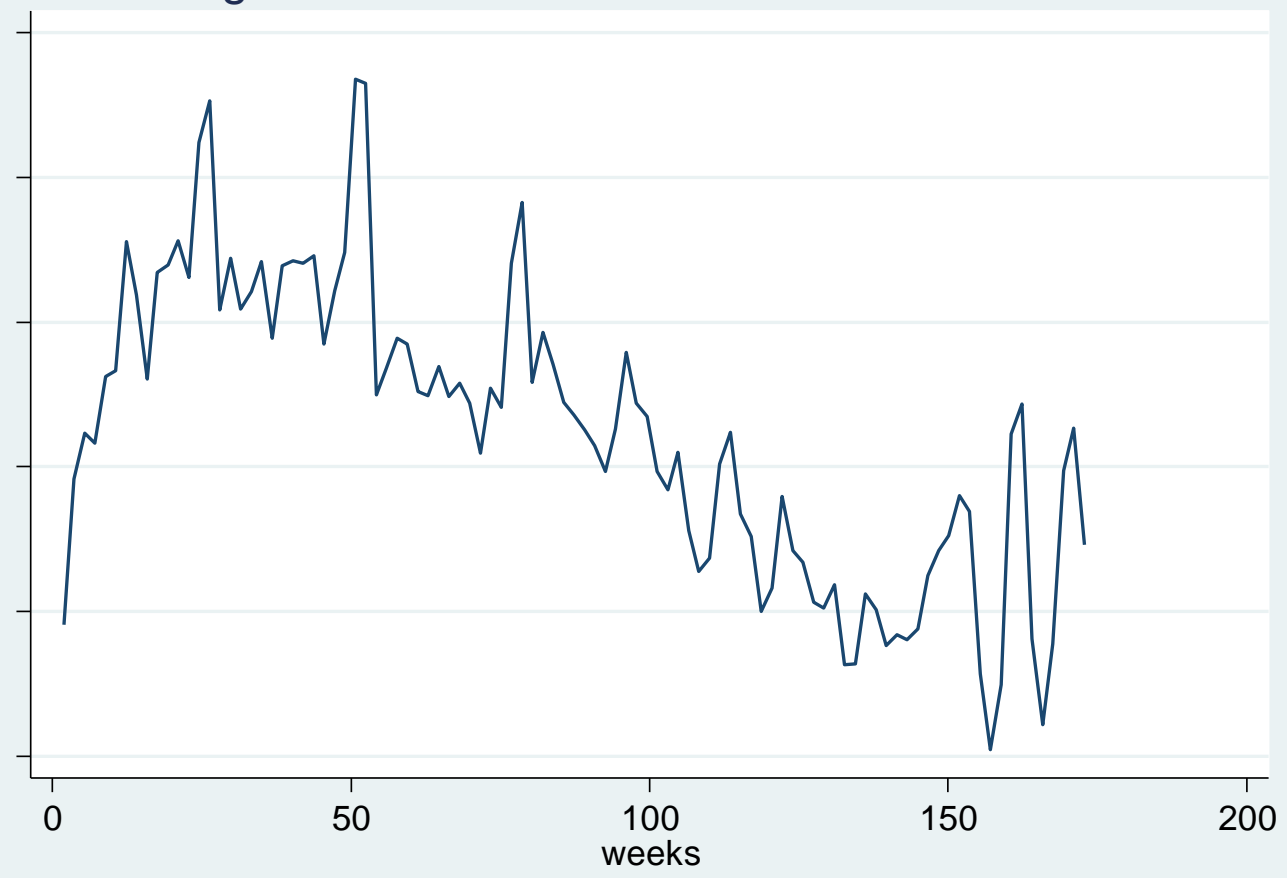


Figure 3: Empirical hazard rate of debt program offer

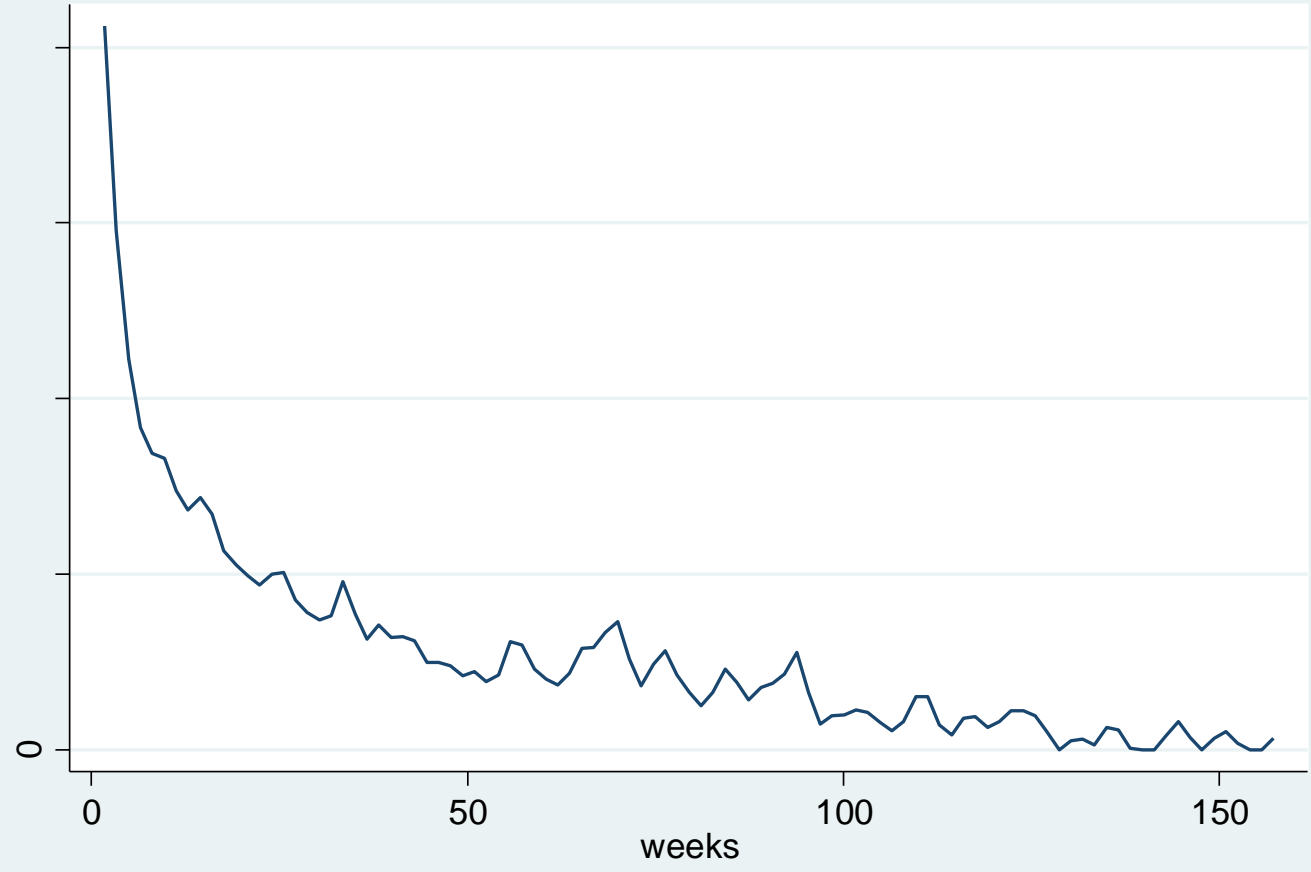

Figure 4: Debt program durations

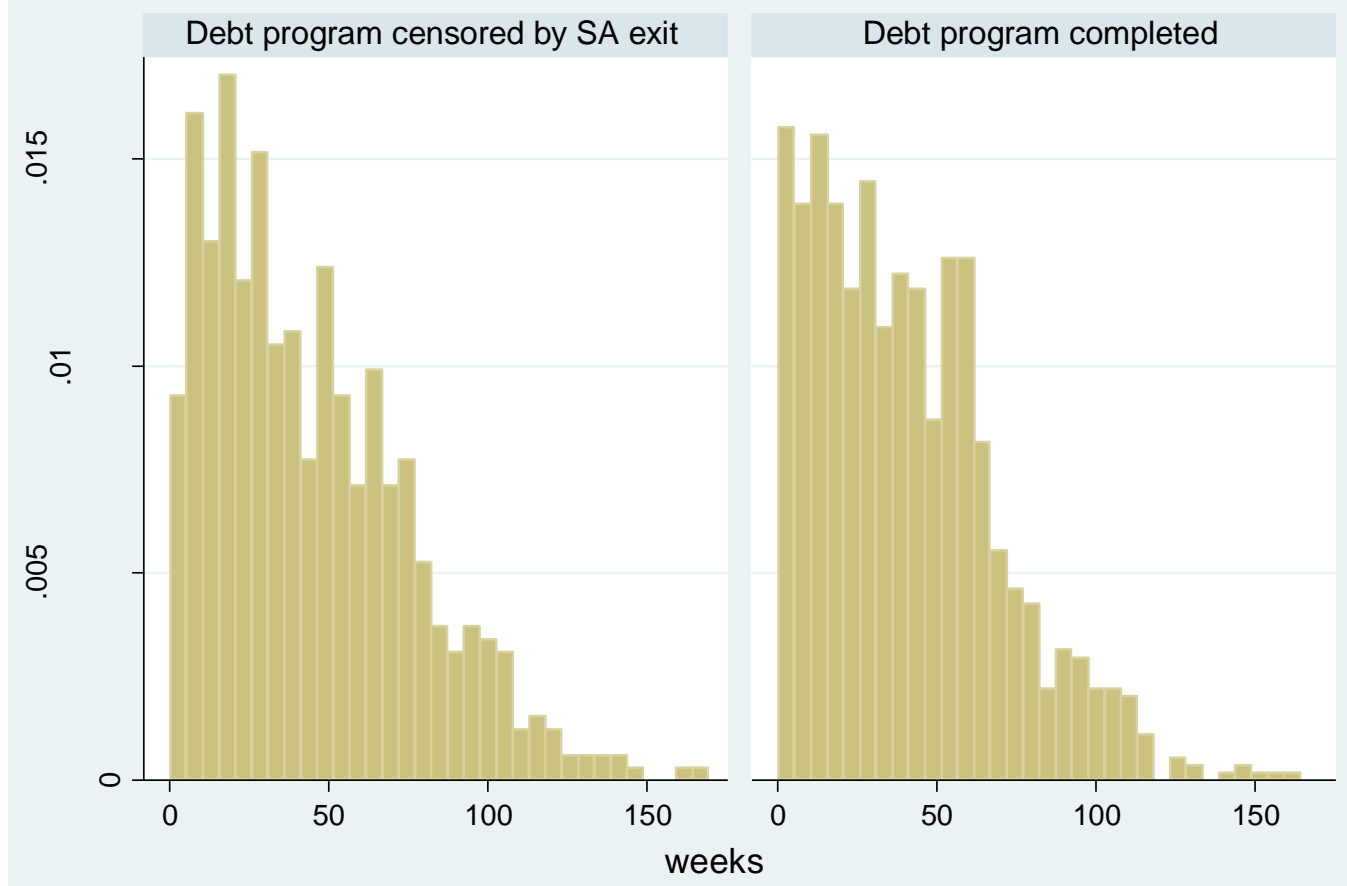




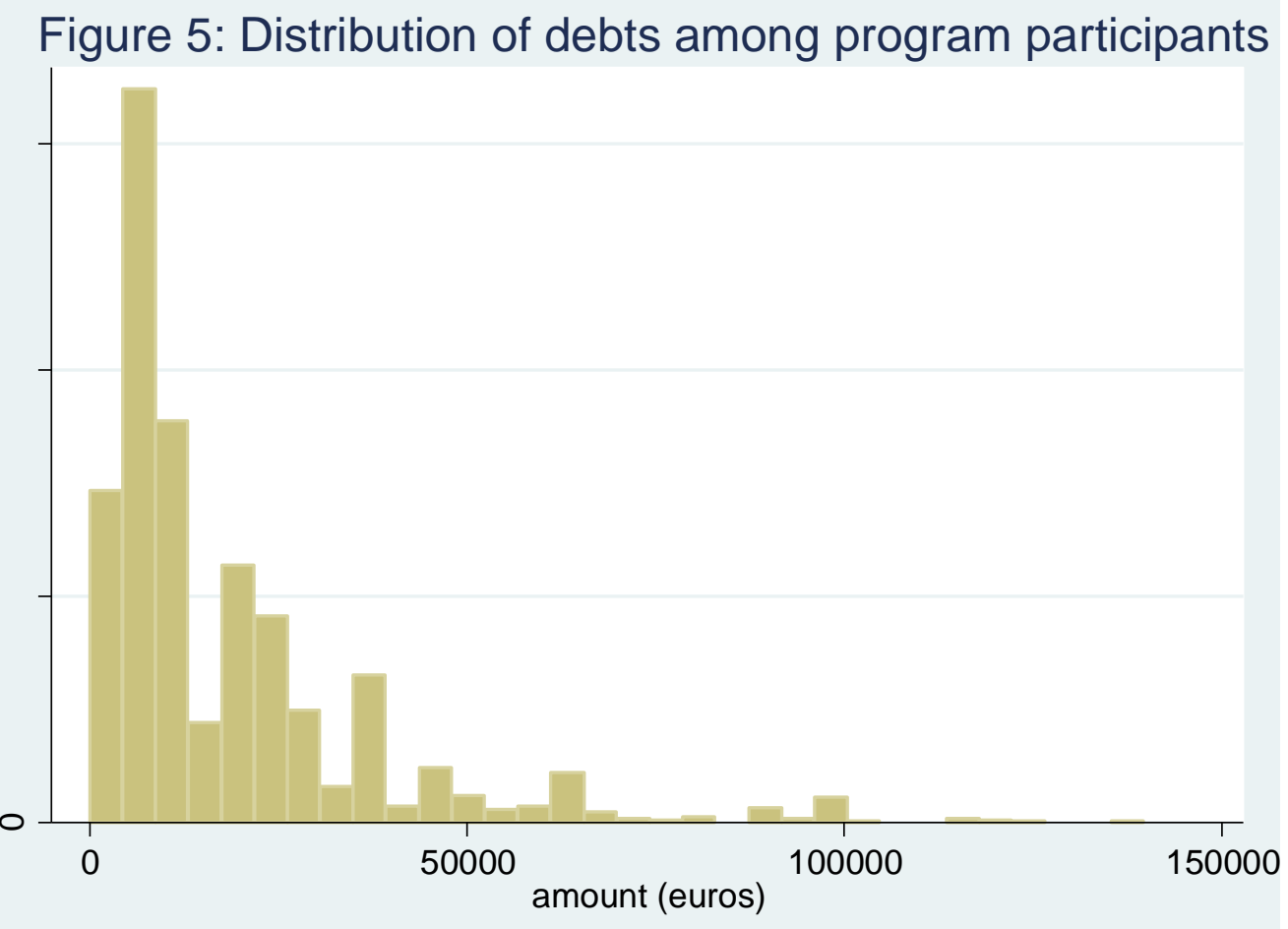

Figure 6: Distribution of number of creditors of program participants

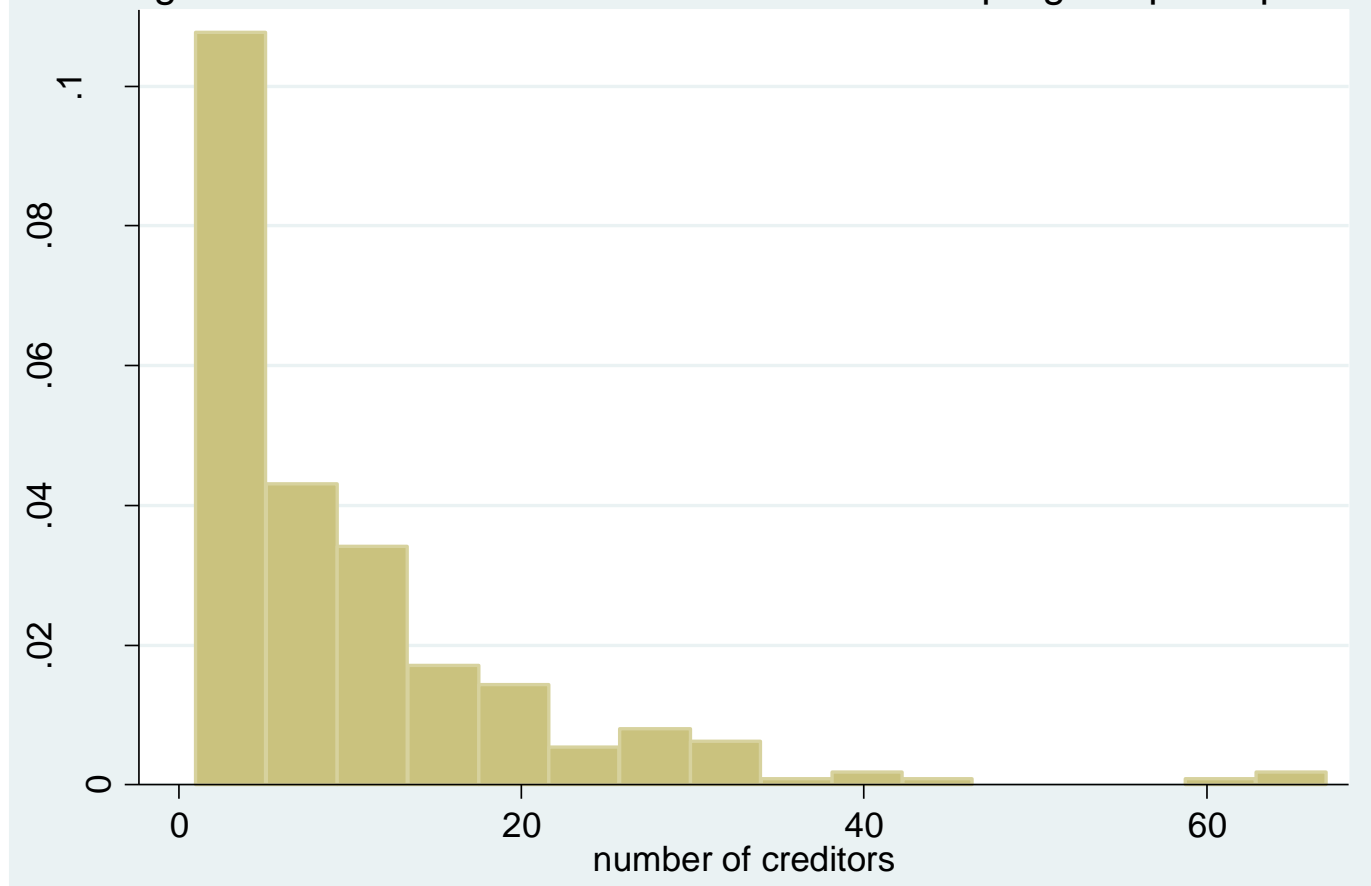


Figure A.1: Return rates into SA

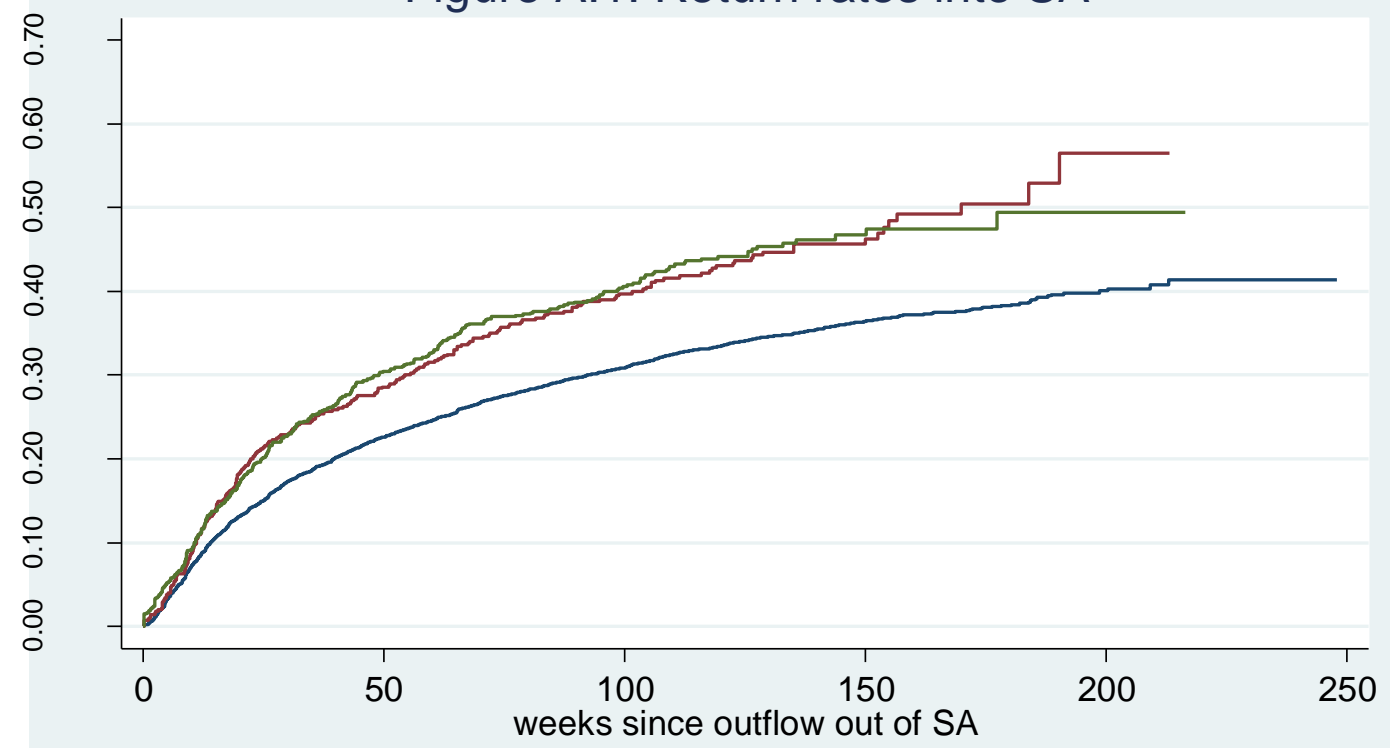

No debt progam offer — Debt program offer; no shows

Debt program participants 